\title{
Assessing the sensitivity of the hydroxyl radical to model biases in composition and temperature using a single-column photochemical model for Lauder, New Zealand
}

\author{
Laura López-Comí $^{1,2}$, Olaf Morgenstern ${ }^{1, \mathrm{a}}$, Guang Zeng ${ }^{1, \mathrm{a}}$, Sarah L. Masters ${ }^{2}$, Richard R. Querel ${ }^{1}$, and Gerald \\ E. Nedoluha ${ }^{3}$ \\ ${ }^{1}$ National Institute of Water and Atmospheric Research (NIWA), Lauder, New Zealand \\ ${ }^{2}$ Department of Chemistry, University of Canterbury, Christchurch, New Zealand \\ ${ }^{3}$ United States Naval Research Laboratory, Washington, DC, USA \\ ${ }^{a}$ now at: NIWA, Wellington, New Zealand
}

Correspondence to: Olaf Morgenstern (olaf.morgenstern@niwa.co.nz)

Received: 26 May 2016 - Published in Atmos. Chem. Phys. Discuss.: 9 June 2016

Revised: 7 October 2016 - Accepted: 2 November 2016 - Published: 23 November 2016

\begin{abstract}
We assess the major factors contributing to local biases in the hydroxyl radical $(\mathrm{OH})$ as simulated by a global chemistry-climate model, using a single-column photochemical model (SCM) analysis. The SCM has been constructed to represent atmospheric chemistry at Lauder, New Zealand, which is representative of the background atmosphere of the Southern Hemisphere (SH) mid-latitudes. We use long-term observations of variables essential to tropospheric $\mathrm{OH}$ chemistry, i.e. ozone $\left(\mathrm{O}_{3}\right)$, water vapour $\left(\mathrm{H}_{2} \mathrm{O}\right)$, methane $\left(\mathrm{CH}_{4}\right)$, carbon monoxide $(\mathrm{CO})$, and temperature, and assess how using these measurements affect $\mathrm{OH}$ calculated in the SCM, relative to a reference simulation only using modelled fields. The analysis spans 1994 to 2010. Results show that $\mathrm{OH}$ responds approximately linearly to correcting biases in $\mathrm{O}_{3}, \mathrm{H}_{2} \mathrm{O}, \mathrm{CO}, \mathrm{CH}_{4}$, and temperature. The biggest impact on $\mathrm{OH}$ is due to correcting an overestimation by approximately 20 to $60 \%$ of $\mathrm{H}_{2} \mathrm{O}$, using radiosonde observations. Correcting this moist bias leads to a reduction of $\mathrm{OH}$ by around 5 to $35 \%$. This is followed by correcting predominantly overestimated $\mathrm{O}_{3}$. In the troposphere, the model biases are mostly in the range of -10 to $30 \%$. The impact of changing $\mathrm{O}_{3}$ on $\mathrm{OH}$ is due to two pathways; the $\mathrm{OH}$ responses to both are of similar magnitude but different seasonality: correcting in situ tropospheric ozone leads to changes in $\mathrm{OH}$ in the range -14 to $4 \%$, whereas correcting the photolysis rate of $\mathrm{O}_{3}$ in accordance with overhead column ozone changes leads to increases of $\mathrm{OH}$ of 8 to $16 \%$. The $\mathrm{OH}$ sensitivities to correcting $\mathrm{CH}_{4}, \mathrm{CO}$, and temperature biases are
\end{abstract}

all minor effects. The work demonstrates the feasibility of quantitatively assessing $\mathrm{OH}$ sensitivity to biases in longerlived species, which can help explain differences in simulated $\mathrm{OH}$ between global chemistry models and relative to observations. In addition to clear-sky simulations, we have performed idealized sensitivity simulations to assess the impact of clouds (ice and liquid) on $\mathrm{OH}$. The results indicate that the impacts on the ozone photolysis rate and $\mathrm{OH}$ are substantial, with a general decrease of $\mathrm{OH}$ below the clouds of up to $30 \%$ relative to the clear-skies situation, and an increase of up to $15 \%$ above. Using the SCM simulation we calculate recent $\mathrm{OH}$ trends at Lauder. For the period of 1994 to 2010, all trends are insignificant, in agreement with previous studies. For example, the trend in total-column $\mathrm{OH}$ is $0.5 \pm 1.3 \%$ over this period.

\section{Introduction}

The hydroxyl radical $(\mathrm{OH})$ is essential to atmospheric chemistry as the leading oxidizing agent. It acts as a "detergent", reacting with numerous, mostly organic pollutants (Levy, 1971; Logan et al., 1981; Thompson, 1992; Lelieveld et al., 2004; Naik et al., 2013) and controls the lifetimes of many trace gases containing carbon-hydrogen bonds, particularly methane $\left(\mathrm{CH}_{4}\right)$, because reaction with $\mathrm{OH}$ is their dominant removal mechanism. It is also responsible for oxidizing at- 
mospheric trace gases such as carbon monoxide (CO), nonmethane volatile organic compounds (NMVOCs), and also some ozone-depleting substances such as hydrochlorofluorocarbons (HCFCs) (DeMore, 1996). Therefore, the oxidizing capacity of the atmosphere is largely defined by the abundance of $\mathrm{OH}$. Tropospheric ozone $\left(\mathrm{O}_{3}\right)$, an air pollutant and greenhouse gas (GHG), is the primary source of $\mathrm{OH}$ in the troposphere. Although it only accounts for $10 \%$ of the total atmospheric $\mathrm{O}_{3}$ abundance, it plays an essential role in photochemical processes controlling tropospheric composition. It forms $\mathrm{OH}$ via $\mathrm{O}_{3}$ photolysis yielding excited oxygen $\left(\mathrm{O}\left({ }^{1} \mathrm{D}\right)\right)$ and a subsequent reaction of $\mathrm{O}\left({ }^{1} \mathrm{D}\right)$ with water vapour $\left(\mathrm{H}_{2} \mathrm{O}\right) . \mathrm{CH}_{4}$ and $\mathrm{CO}$ oxidation by $\mathrm{OH}$, and other oxidation processes involving NMVOCs, lead to formation of tropospheric $\mathrm{O}_{3}$ in the presence of $\mathrm{NO}_{x}$ (Logan et al., 1981; Thompson, 1992; Lelieveld and Dentener, 2000). In low- $\mathrm{NO}_{x}$ atmospheric environments, such as in much of the $\mathrm{SH}$, downward transport of $\mathrm{O}_{3}$ from the stratosphere is the main source of tropospheric $\mathrm{O}_{3}$, followed by $\mathrm{O}_{3}$ transport from other regions where it is chemically produced (Zeng et al., 2010). Stratospheric $\mathrm{O}_{3}$ also plays an important role through its impact on the $\mathrm{O}_{3}$ photolysis rate $j_{\mathrm{O}^{1} \mathrm{D}}$ which is affected by the overhead $\mathrm{O}_{3}$ column. For instance, stratospheric $\mathrm{O}_{3}$ depletion produces increased UV penetration to the troposphere. This affects the production of tropospheric $\mathrm{OH}$.

The most widely used method for field measurements of $\mathrm{OH}$ is the Fluorescence Assay by Gas Expansion (FAGE) technique and is based on the measurement of $\mathrm{OH}$ and other species concentrations through ultra-violet (UV) laserinduced fluorescence spectroscopy. $\mathrm{OH}$ measurements using the FAGE technique have been conducted in a large variety of atmospheric environments, ranging from polluted (Ren et al., 2003; Dusanter et al., 2009) to clean (Creasey et al., 2003; Bloss et al., 2007) atmospheres. However, due to its very short lifetime (the global lifetime is estimated to be $\sim 1 \mathrm{~s}$, Prinn, 2001; Elshorbany et al., 2012) and large variability, such in situ measurements of $\mathrm{OH}$ do not sufficiently capture its global abundance, which makes it difficult to sufficiently constrain global $\mathrm{OH}$ abundances with in situ measurements (Heard and Pilling, 2003). For that reason, modelling is an essential tool to study global $\mathrm{OH}$. $\mathrm{OH}$ is routinely included in global models of tropospheric chemistry, but the complexity of the tropospheric chemical system and the sensitivity of $\mathrm{OH}$ to a variety of environmental factors mean that there is considerable disagreement among global chemistrytransport and chemistry-climate models regarding the global $\mathrm{OH}$ abundance; this is often expressed in terms of the $\mathrm{CH}_{4}$ lifetime (e.g. Stevenson et al., 2006; Naik et al., 2013; Voulgarakis et al., 2013). Several model studies have examined changes in $\mathrm{OH}$ abundance and the $\mathrm{CH}_{4}$ lifetime since pre-industrial times. Chemistry-transport models (which use off-line, precalculated meteorology) generally simulate decreases in $\mathrm{OH}$ and increases in the $\mathrm{CH}_{4}$ lifetime, ranging from 6 to $25 \%$ during the 21 st century (Thompson, 1992;
Lelieveld et al., 1998; Wild and Palmer, 2008). These results differ from those produced by chemistry-climate models which account for changes in both emissions and climate (Stevenson et al., 2000; Johnson et al., 2001; Shindell et al., 2006; Zeng et al., 2010; John et al., 2012). All of them project a reduction in the $\mathrm{CH}_{4}$ lifetime and an increase in $\mathrm{OH}$. In particular, Shindell et al. (2006) and Zeng et al. (2010) obtain a $\sim 10 \%$ decrease in the $\mathrm{CH}_{4}$ lifetime using different emission scenarios in their simulations. More recent and comprehensive studies compare present-day and future results for $\mathrm{OH}$ and the $\mathrm{CH}_{4}$ lifetime among models participating in the Atmospheric Chemistry and Climate Model Intercomparison Project (ACCMIP, Naik et al., 2013; Voulgarakis et al., 2013). Naik et al. (2013) analyse the evolution of the $\mathrm{CH}_{4}$ lifetime and $\mathrm{OH}$ in ACCMIP models since preindustrial times (1850-2000). They point out large variations in the sign and magnitude of $\mathrm{OH}$ changes (from $-12.7 \%$ to $14.6 \%$ ) amongst ACCMIP models, reflecting uncertainties in natural $\mathrm{CO}, \mathrm{NO}_{x}$, and NMVOC emissions as well as roles of the diverse chemical mechanisms included in the models. For present-day (year 2000) simulations of $\mathrm{OH}$ and the $\mathrm{CH}_{4}$ lifetime, Voulgarakis et al. (2013) suggest that diversity in photolysis schemes and NMVOC emissions might cause large variations in simulated $\mathrm{OH}$ and the $\mathrm{CH}_{4}$ lifetime. Trends in $\mathrm{OH}$ between 2000 and 2100 are mainly attributed to stratospheric $\mathrm{O}_{3}$ changes and trends in modelled temperature fields.

A useful indirect method for constraining global $\mathrm{OH}$ is based on tracking the abundance of long-lived, well mixed chemicals for which oxidation by $\mathrm{OH}$ is the dominant sink and which have a well quantified, industrial source. The most widely used such species is methyl chloroform $\left(\mathrm{CH}_{3} \mathrm{CCl}_{3}\right)$ (Prinn et al., 2005; Bousquet et al., 2005; Manning et al., 2005; Krol et al., 2008). Montzka et al. (2011) use $\mathrm{CH}_{3} \mathrm{CCl}_{3}$ measurements to infer only a small interannual variability in OH for 1998-2007. The global multi-model mean $\mathrm{OH}$ inferred from the ACCMIP ensemble (Naik et al., 2013) increases slightly $(3.5 \pm 2.2 \%)$ over the period $1980-2000$. This result largely agrees with Montzka et al. (2011) and with other models (Dentener et al., 2003; Hess and Mahowald, 2009; John et al., 2012; Holmes et al., 2013), but disagree with other studies of $\mathrm{CH}_{3} \mathrm{CCl}_{3}$ observations that find a decrease in OH over that period (Prinn, 2001; Bousquet et al., 2005). For the year 2000, Naik et al. (2013) underestimate the $\mathrm{CH}_{3} \mathrm{CCl}_{3}$ lifetime (and thus overestimate $\mathrm{OH}$ ) by 5 to $10 \%$ relative to observations. $\mathrm{CH}_{3} \mathrm{CCl}_{3}$ is controlled under the Montreal Protocol, meaning its abundance in the atmosphere is approaching the detection limit and it will no longer be a useful constraint on $\mathrm{OH}$ in decades to come.

A further indirect method to address $\mathrm{OH}$ is to measure ${ }^{14} \mathrm{CO}$. Manning et al. (2005) find some considerable variability but no long-term trend using this method. According to Krol et al. (2008), this method is considerably more sensitive to high-latitude than low-latitude $\mathrm{OH}$, in contrast to the $\mathrm{CH}_{3} \mathrm{CCl}_{3}$ method which is mostly sensitive to tropical $\mathrm{OH}$. 
Therefore, a step forward in addressing the uncertainty in modelling $\mathrm{OH}$ in global models is to quantitatively assess the contributions of biases in long-lived species that are central to $\mathrm{OH}$. This sometimes involves juxtaposing global models to local-scale (box or single-column) models constrained as much as possible by observations and incorporating only fast photochemical processes. For example, Emmerson et al. (2005, 2007) develop a box model to assess the sensitivity of $\mathrm{OH}$ and $\mathrm{HO}_{2}$ to biases in long-lived species, and compare the model results to observations. However, their analyses only pertain to polluted environments not representative of much of the global atmosphere and only take in episodic and surface measurements. Single-column models have been applied to modelling the atmospheric boundary layer (Mihailovic et al., 2005; Cuxart et al., 2006), diabatic processes (Randall et al., 2003; Bergman and Sardeshmukh, 2004), clouds and aerosols (Kylling et al., 2005; Lebassi-Habtezion and Caldwell, 2015; Dal Gesso et al., 2015), the impacts of GHGs on climate change (Vupputuri et al., 1995), and the chemistry of halogen compounds (Piot and von Glasow, 2008; Joyce et al., 2014). Tropospheric OH chemistry of the remote atmosphere has not been assessed in a single-column model framework before.

In the present paper, we introduce and evaluate a singlecolumn model (SCM) constrained with available long-term observations at Lauder, New Zealand $\left(45^{\circ} \mathrm{S}, 170^{\circ} \mathrm{E}, 370 \mathrm{~m}\right.$ above sea level), to investigate how chemistry-climate model biases in long-lived chemical species and temperature affect $\mathrm{OH}$. Lauder is known for its clean air (Stedman and McEwan, 1983; McKenzie et al., 2008) and large diversity of available measurements (it is part of the Network for the Detection of Atmospheric Composition Change (NDACC), Badosa et al., 2007; McKenzie et al., 2008; WMO, 2011). Observations made at Lauder include UV radiation and surface, profile, and/or total columns of $\mathrm{O}_{3}$ and several other species. The $\mathrm{O}_{3}, \mathrm{H}_{2} \mathrm{O}$, and temperature records produced by ozone sondes cover 1986 to the present. Lauder therefore is ideal for this kind of study. The SCM is built around a mediumcomplexity stratosphere-troposphere chemistry scheme. The model is forced with Lauder observations and/or output from a chemistry-climate model that uses the same scheme (see below). In Sect. 2, we describe the set-up of the SCM, the construction of time series of key species and meteorological parameters that drive the SCM, and the simulations. In Sect. 3, we present results of simulated $\mathrm{OH}$ concentrations and trends from the SCM and analyse the sensitivity of $\mathrm{OH}$ to various forcings. Conclusions are gathered in Sect. 4.

\section{Models and simulations}

\subsection{The single-column photochemical model (SCM)}

The single-column photochemical model is a stand-alone version of the stratosphere-troposphere chemistry mecha- nism used by the National Institute of Water and Atmospheric Research (NIWA) and United Kingdom Chemistry and Aerosol (UKCA) model (NIWA-UKCA), which comprises gas-phase photochemical reactions relevant to the troposphere and stratosphere (Morgenstern et al., 2009, 2013; Telford et al., 2013; O'Connor et al., 2014; Morgenstern et al., 2016). For consistency with NIWA-UKCA, the SCM uses the same chemical mechanism. Had we used a more complex mechanism (which the SCM approach lends itself to), then a direct comparison with the NIWA-UKCA output would no longer be possible, and also the results would be less relevant to other global CCMs characterized by relatively simple chemical mechanisms. The 60 vertical levels of the SCM are the same as in NIWA-UKCA, extending to $84 \mathrm{~km}$. We do not use horizontal interpolation and take profiles of atmospheric properties from the grid point closest to Lauder $\left(45^{\circ} \mathrm{S}, 168.75^{\circ} \mathrm{E}\right)$. Unlike NIWA-UKCA, the SCM excludes all non-chemistry processes, such as transport, dynamics, the boundary-layer scheme, radiation, emissions, etc. This means the model is only suitable for assessing fast photochemistry. Forcing data for the SCM are mostly interpolated from 10-daily instantaneous outputs from a NIWAUKCA simulation (see below), except for those fields for which observational data are used.

Morgenstern et al. (2013) and O'Connor et al. (2014) describe the chemistry scheme included in the SCM. The SCM includes an isoprene oxidation scheme (Pöschl et al., 2000; Zeng et al., 2008; Morgenstern et al., 2016) not included in the NIWA-UKCA model version used by Morgenstern et al. (2013). In addition to $\mathrm{CH}_{4}$ and $\mathrm{CO}$, the model includes a number of primary NMVOC source gases, i.e. ethane $\left(\mathrm{C}_{2} \mathrm{H}_{6}\right)$, propane $\left(\mathrm{C}_{3} \mathrm{H}_{6}\right)$, acetone $\left(\mathrm{CH}_{3} \mathrm{COCH}_{3}\right)$, formaldehyde $(\mathrm{HCHO})$, acetaldehyde $\left(\mathrm{CH}_{3} \mathrm{CHO}\right)$, and isoprene $\left(\mathrm{C}_{5} \mathrm{H}_{8}\right)$. As noted above, emission and deposition of species are not considered in the SCM. The SCM includes a comprehensive formulation of stratospheric chemistry (Morgenstern et al., 2009) comprising bromine and chlorine chemistry and heterogeneous processes on liquid sulfate aerosols. Overall, the model represents 86 chemical species and 291 reactions including 59 photolysis and 5 heterogeneous reactions. The FAST-JX interactive photolysis scheme (Neu et al., 2007; Telford et al., 2013) has been implemented in the SCM; this scheme solves a radiative transfer equation accounting for absorption by ozone. The chemical integration is organized through a self-contained atmospheric chemistry package (Carver et al., 1997), and the differential equations describing chemical kinetics are solved using a Newton-Raphson solver (Morgenstern et al., 2009).

\subsection{Construction of vertical profiles of forcing species and meteorological parameters}

Time series of $\mathrm{O}_{3}, \mathrm{H}_{2} \mathrm{O}, \mathrm{CO}$, and temperature profiles are produced using mainly long-term measurements from Lauder, supplemented with NIWA-UKCA results as de- 
(a) $\mathrm{O}$

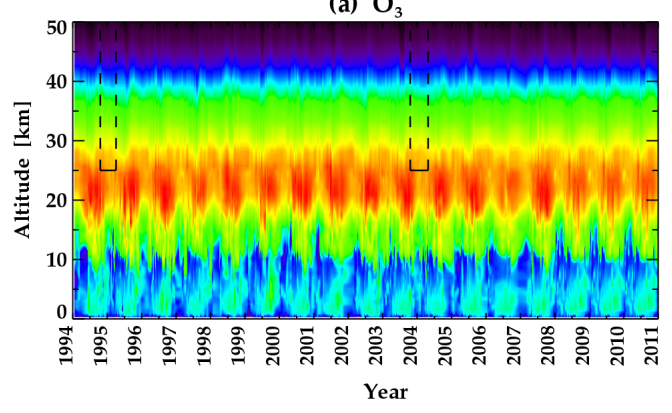

$\mathrm{O}_{3}\left[10^{12}\right.$ molec $\left.\mathrm{cm}^{-3}\right]$

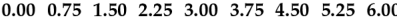

(c) $\mathrm{CH}_{4}$

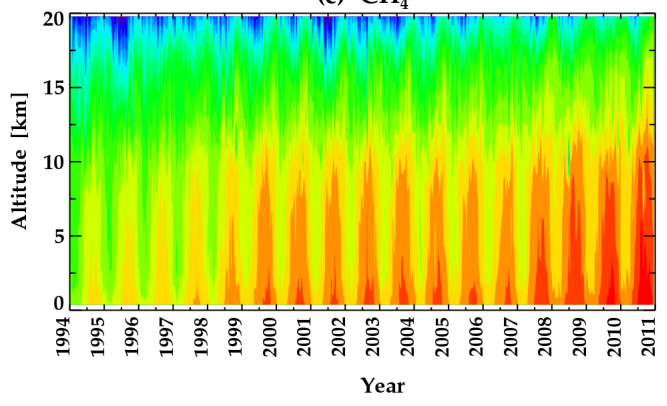

$\mathrm{CH}_{4}\left[10^{-7} \mathrm{~kg} \mathrm{~kg}^{-1}\right]$

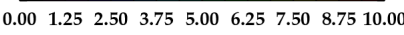

(b) $\mathrm{H}_{2} \mathrm{O}$

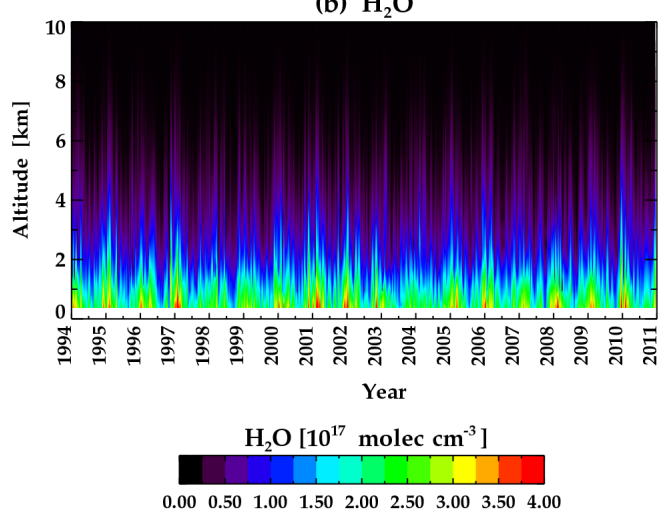

(d) $\mathrm{CO}$

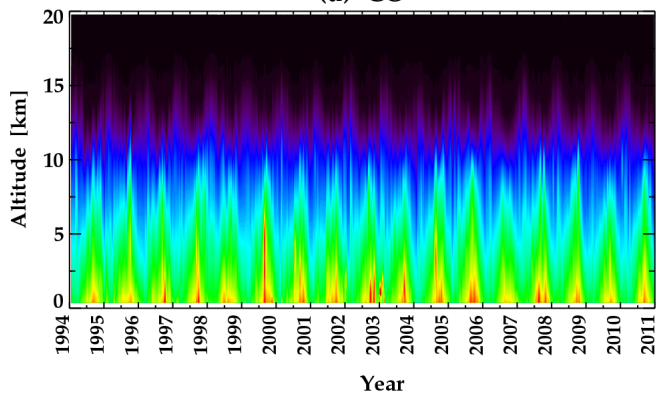

CO $\left[10^{12}\right.$ molec $\left.\mathrm{cm}^{-3}\right]$

$\begin{array}{llllllllll}0.00 & 0.25 & 0.50 & 0.75 & 1.00 & 1.25 & 1.50 & 1.75 & 2.00\end{array}$

(e) Temperature

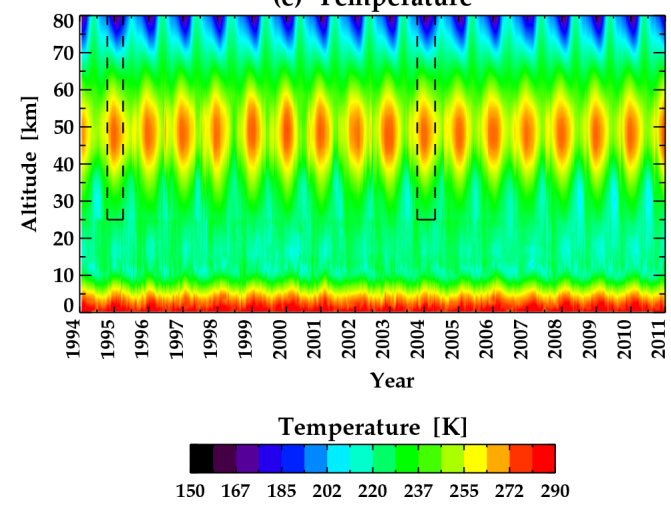

Figure 1. (a) Time series of $\mathrm{O}_{3}$ profiles constructed by ozone sonde measurements spliced with MOPI1 measurements. (b) Time series of $\mathrm{H}_{2} \mathrm{O}$ profiles constructed by radiosonde measurements spliced with NIWA-UKCA $\mathrm{H}_{2} \mathrm{O}$ (time series of ERAI - NIWA-UKCA $\mathrm{H}_{2} \mathrm{O}$ is not displayed here). (c) Time series of $\mathrm{CH}_{4}$ profiles constructed by rescaling the NIWA-UKCA $\mathrm{CH}_{4}$ to surface $\mathrm{CH}_{4}$ measurements from Cape Grim (Tasmania). (d) Time series of CO profiles constructed by rescaling the NIWA-UKCA CO to CO measurements from the FTIR spectrometer. (e) Time series of temperature profiles constructed by radiosonde measurements (up to $25 \mathrm{~km}$ ) merged with NCEP/NCAR reanalyses up to the stratopause $(50 \mathrm{~km})$ and a mesospheric climatology based on local lidar measurements. Above $25 \mathrm{~km}$ these data are as used in the retrieval of $\mathrm{O}_{3}$ from MOPI1 measurements. The areas within black boxes were filled using a Fourier series gap filling method. 
Table 1. Simulations performed with the SCM to assess the contribution of changes in the key forcings to OH chemistry at Lauder under clear-sky conditions. The table includes the type of measurement/dataset used to prescribe the key forcings. The time period of simulation is between 1994 and 2010.

\begin{tabular}{|c|c|}
\hline Forcings & Data used \\
\hline $\mathrm{O}_{3}$ & $\begin{array}{l}\text { 1. Kinetics effect: } \mathrm{O}_{3} \text { changes } \rightarrow \text { ozone sondes }(0-25 \mathrm{~km})+\text { MOPI } 1(26-84 \mathrm{~km}) \\
\text { NIWA-UKCA data for other species and temperature } \\
\text { 2. Photolysis effect: } j_{\mathrm{O}^{1} \mathrm{D}} \text { changes according to } \mathrm{O}_{3} \text { changes } \\
\text { NIWA-UKCA data for all species and temperature } \\
\text { 3. Kinetics + photolysis effects: } \mathrm{O}_{3} \text { changes } \rightarrow \text { ozone sondes + MOPI1 } \\
j_{\mathrm{O}^{1} \mathrm{D}} \text { changes according to } \mathrm{O}_{3} \text { changes } \\
\text { NIWA-UKCA data for other species and temperature }\end{array}$ \\
\hline $\mathrm{H}_{2} \mathrm{O}$ & $\begin{array}{l}\text { 1. Changes in } \mathrm{H}_{2} \mathrm{O} \rightarrow \text { radiosondes }(0-8 \mathrm{~km})+\text { NIWA-UKCA } \mathrm{H}_{2} \mathrm{O}(9-84 \mathrm{~km}) \\
\text { NIWA-UKCA data for other species and temperature } \\
\text { 2. Changes in } \mathrm{H}_{2} \mathrm{O} \rightarrow \text { ERAI }(0-8 \mathrm{~km})+\text { NIWA-UKCA } \mathrm{H}_{2} \mathrm{O}(9-84 \mathrm{~km}) \\
\text { NIWA-UKCA data for other species and temperature. }\end{array}$ \\
\hline $\mathrm{CH}_{4}$ & $\begin{array}{l}\text { Changes in } \mathrm{CH}_{4} \rightarrow \text { rescaled NIWA-UKCA } \mathrm{CH}_{4} \text { to Cape Grim surface } \mathrm{CH}_{4} \\
\text { NIWA-UKCA data for other species and temperature. }\end{array}$ \\
\hline $\mathrm{CO}$ & $\begin{array}{l}\text { Changes in } \mathrm{CO} \rightarrow \text { rescaled NIWA-UKCA CO profiles to FTIR CO } \\
\text { NIWA-UKCA data for other species and temperature }\end{array}$ \\
\hline \multirow[t]{4}{*}{$T$} & $\begin{aligned} \text { 1. Kinetics effect: temperature changes } \rightarrow & \text { radiosondes }(\text { surface }-25 \mathrm{~km})+ \\
& \text { lidar climatology }(50-84 \mathrm{~km})\end{aligned}$ \\
\hline & $\begin{array}{l}\text { NIWA-UKCA data for all species } \\
\text { 2. Photolysis effect: } j_{\mathrm{O}^{1} \mathrm{D}} \text { changes according to temperature changes } \\
\text { NIWA-UKCA data for all species and temperature }\end{array}$ \\
\hline & $\begin{aligned} \text { 3. Kinetics }+ \text { photolysis effects: temperature changes } \rightarrow & \text { radiosondes }(\text { surface }-25 \mathrm{~km})+ \\
& \text { lidar climatology }(50-84 \mathrm{~km})\end{aligned}$ \\
\hline & $\begin{array}{l}j_{\mathrm{O}^{1} \mathrm{D}} \text { changes according to temperature changes } \\
\text { NIWA-UKCA data for all species }\end{array}$ \\
\hline $\begin{array}{l}\mathrm{O}_{3}, \mathrm{H}_{2} \mathrm{O} \\
\mathrm{CH}_{4}, \mathrm{CO}, T\end{array}$ & $\begin{array}{l}\text { Changes in } \mathrm{O}_{3}, \mathrm{H}_{2} \mathrm{O}, \mathrm{CH}_{4}, \mathrm{CO} \text {, and temperature using observations mentioned above. } \\
\text { For } \mathrm{H}_{2} \mathrm{O} \text {, radiosonde }(0-8 \mathrm{~km})+\text { NIWA-UKCA }(9-84 \mathrm{~km}) \text { data are used. }\end{array}$ \\
\hline Reference & NIWA-UKCA data for all species and temperature \\
\hline
\end{tabular}

tailed below. Lauder is a member of several international networks, including the NDACC (http://www.ndsc. ncep.noaa.gov), the Global Reference Upper Air Network (GRUAN; http://www.gruan.org), and Global Atmosphere Watch (GAW; http://www.wmo.int/pages/prog/arep/ gaw/gaw_home_en.html), where these data are archived and made available. The networks coordinate long-term observations of $\mathrm{O}_{3}$, various other constituents, and meteorological parameters. Here we briefly describe the procedure of constructing forcing data, using Lauder observations, to be used to constrain the SCM. The resulting profiles are shown in Fig. 1.

$\mathrm{O}_{3}$ profiles used here are a combination of ozone sonde time series (from the surface to $25 \mathrm{~km}$, Bodeker et al., 1998) combined with the Microwave Ozone Profiler Instrument 1 (MOPI1) time series for altitudes above $25 \mathrm{~km}$ (Boyd et al., 2007; Nedoluha et al., 2015), covering 1994 to 2010
(Fig. 1a). The ozone sondes have been launched approximately weekly; this defines the temporal coverage of the forcing data used in the SCM calculations. Microwave measurements used here come as several profiles a day at a variable spacing; we interpolate them to the ozone sonde launch times. Any missing data (during the two periods when the microwave instrument was out of service) are filled using a Fourier series gap-filling method. We compare the two datasets in the height region usefully covered by both $(20$ to $30 \mathrm{~km}$ ). The differences between the two measurements range between -2 and $+6 \%$, and a mean bias that is less than $5 \% . \mathrm{O}_{3}$ profiles are linearly interpolated onto the SCM's grid. Total column ozone calculated by integrating the observed $\mathrm{O}_{3}$ profiles is also compared to total-column $\mathrm{O}_{3}$ measured by the Lauder Dobson instrument; the difference is about $5 \%$ on average (López Comí, 2016). Lauder ozone measurements have been used in various World Meteoro- 
logical Organization (WMO) ozone assessments (e.g. WMO, 2011).

$\mathrm{H}_{2} \mathrm{O}$ profiles have been constructed using the weekly radiosonde measurements of $\mathrm{H}_{2} \mathrm{O}$ vapour below $8 \mathrm{~km}$ (the same soundings that also measure ozone) and NIWA-UKCA model output data above. For validation, we use the monthly National Atmospheric and Oceanic Administration (NOAA) Frost Point Hygrometer (FPH) $\mathrm{H}_{2} \mathrm{O}$ vapour measurements (Vömel et al., 2007; Hall et al., 2016), which start in 2003. FPHs are more accurate compared to radiosonde hygrometers, particularly for stratospheric conditions. However, due to the later start of the FPH time series and the lower measurement frequency, radiosonde measurements are used in this study. The comparison of FPH and radiosonde $\mathrm{H}_{2} \mathrm{O}$ reveals differences that are generally less than $\pm 5 \%$ in the lower and middle troposphere but generally increase in and above the tropopause region ( $11 \mathrm{~km}$, López Comí, 2016). The radiosonde hygrometers have some known problems with measuring low humidity (Miloshevich et al., 2001). This is reflected in the large differences observed particularly at these altitudes (up to $30 \%$ ) and, to a lesser degree, below them (Fig. 2a). In a comparison of NIWA-UKCA output with $\mathrm{FPH} \mathrm{H}_{2} \mathrm{O}$, larger discrepancies are found throughout the whole troposphere and tropopause region (Fig. 2b), as can be expected from a low-resolution model unconstrained by observations and subject to problems with modelling $\mathrm{H}_{2} \mathrm{O}$. Given the consistency of FPH and radiosonde $\mathrm{H}_{2} \mathrm{O}$ below $8 \mathrm{~km}$ found before, here we use radiosonde data up to $8 \mathrm{~km}$ of altitude merged, in the absence of a more suitable dataset, with NIWA-UKCA output above that.

We use surface in situ measurements from Cape Grim, Tasmania (Cunnold et al., 2002) to rescale NIWA-UKCA model profiles, producing $\mathrm{CH}_{4}$ profiles that coincide with the ozone sonde launches. The NIWA-UKCA model simulation had been constrained with historical global-mean surface $\mathrm{CH}_{4}$ values, resulting in an overestimation relative to the Cape Grim data by $\sim 2 \%$ (not shown), and both data show a $\sim 5 \%$ increase in $\mathrm{CH}_{4}$ at the surface over the period between 1994 and 2010. Cape Grim $\mathrm{CH}_{4}$ is a good surrogate for the Lauder measurements because $\mathrm{CH}_{4}$ is a long-lived, well-mixed atmospheric constituent.

The time series of CO profile over the period of 19942010 has been constructed using the NIWA-UKCA CO profiles, rescaled such that the total columns match those obtained from the mid-infrared Fourier Transform Spectrometer (FTS) at Lauder (Rinsland et al., 1998; Zeng et al., 2012; Morgenstern et al., 2012). Gaps in the total-column FTS series, such as the period between 1994 and 1996 when the FTS measurements had not started yet, are filled using a regression fit accounting for the mean annual cycle (modelled as a 6-term harmonic series) and the linear trend.

The time series of temperature profiles are constructed following the same procedure as used in the construction of $\mathrm{O}_{3}$ profiles, comprising the radiosonde temperature profiles (from the surface to $25 \mathrm{~km}$ ) merged with NCEP/NCAR

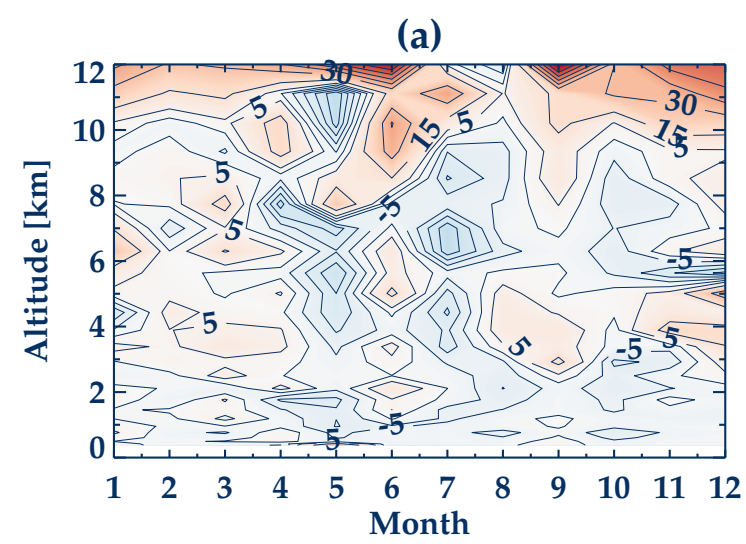

(b)

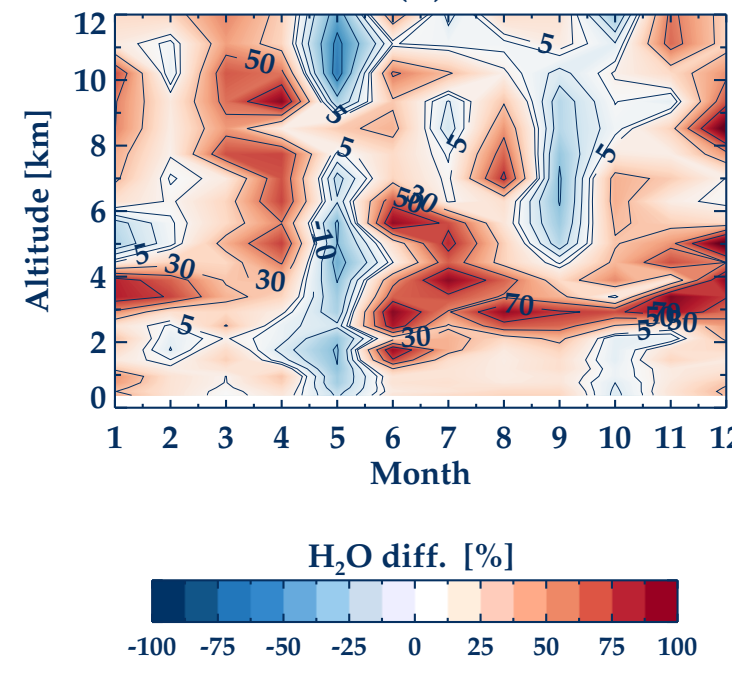

Figure 2. (a) Multi-annual and monthly mean percentage differences between radiosonde and $\mathrm{FPH} \mathrm{H}_{2} \mathrm{O}$ measurements. (b) Multiannual and monthly-mean percentage differences between NIWAUKCA output and $\mathrm{FPH} \mathrm{H}_{2} \mathrm{O}$.

reanalyses (Kalnay et al., 1996) temperatures used in the retrieval of MOPI1 ozone (above $25 \mathrm{~km}$ ) for the period of 1994-2010. From near the stratopause upwards the NCEP/NCAR temperatures are merged with a mesospheric climatology based on local lidar measurements. There are some warm anomalies occurring in the data at $40-60 \mathrm{~km}$ during winter months (e.g. in 1996); these may reflect planetary wave breaking in the upper stratosphere.

\subsection{Simulations}

We perform SCM simulations covering the period of 19942010, summarized in Table 1. The forcing data needed by the SCM consist of profile series of temperature, pressure, optional cloud liquid and ice mass mixing ratios, and the mixing ratios of 86 chemical compounds. With the exceptions detailed below, these fields and species are taken from a NIWA-UKCA simulation for the period of 1994-2010 inter- 
(a) $\mathrm{O}_{3}$ biases $[\%]$

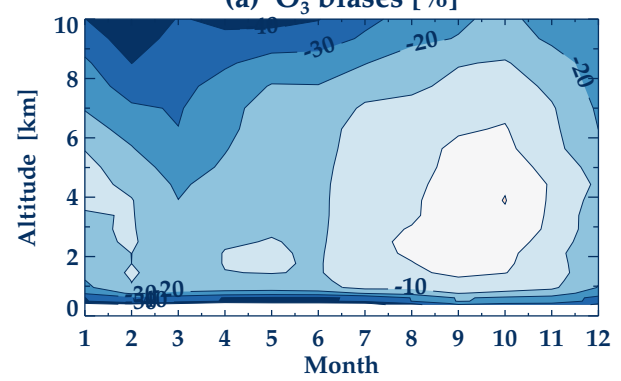

(c) $\mathrm{jO}\left({ }^{1} \mathrm{D}\right)$ biases $[\%]$

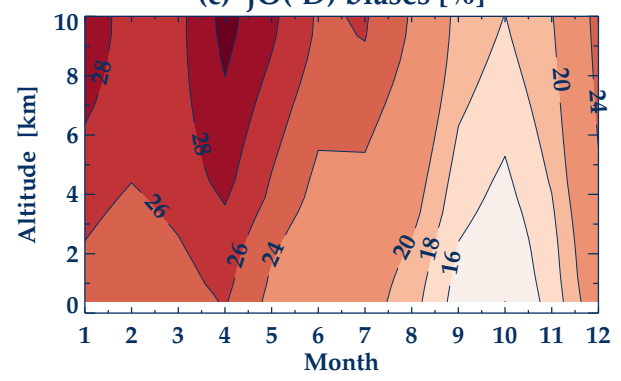

(e) $\mathrm{OH}$ response to photolysis and kinetics [\%]

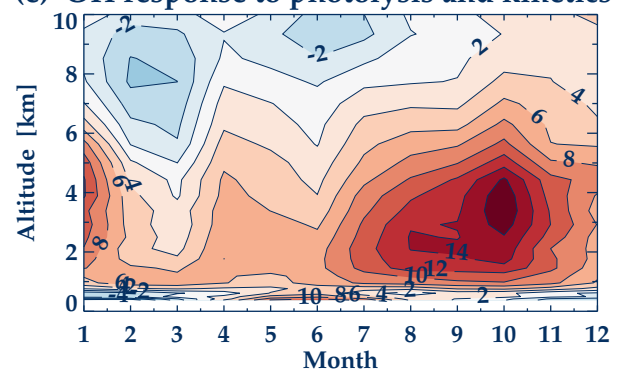

(b) $\mathrm{OH}$ response to kinetics [\%]

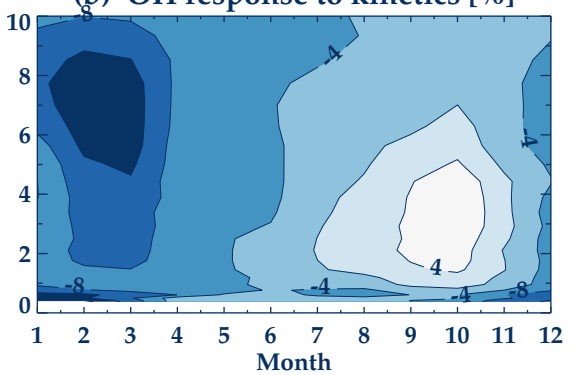

(d) $\mathrm{OH}$ response to photolysis [\%]

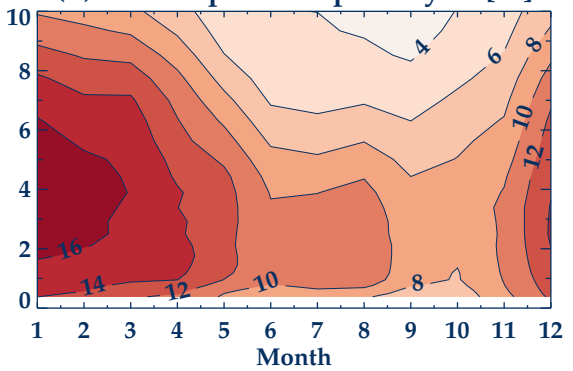

(f) Result of summing (b) and (d) [\%]

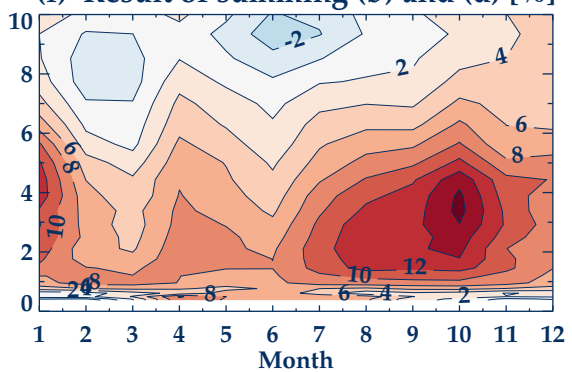

Figure 3. Multi-annual and monthly-mean $\mathrm{OH}$ responses to $\mathrm{O}_{3}$ biases between observations and the reference simulation. (a) Difference in $\mathrm{O}_{3}(\%)$ between ozone sonde and NIWA-UKCA ozone, relative to NIWA-UKCA ozone as prescribed in the reference simulation. (b) OH difference $(\%)$ relative to the reference simulation accounting only for the kinetics effects of $\mathrm{O}_{3}$ differences (e.g. with $j_{\mathrm{O}^{1} \mathrm{D}}$ unchanged). (c) Difference in $j_{\mathrm{O}^{1} \mathrm{D}}(\%)$ relative to the reference simulation. (d) $\mathrm{OH}$ difference (\%) relative to the reference simulation accounting only for $j_{\mathrm{O}^{1} \mathrm{D}}$ differences (e.g. with $\mathrm{O}_{3}$ unchanged). (e) $\mathrm{OH}$ differences relative to the reference simulation considering the combined kinetics and photolysis effects. (f) Sum of (b) and (d).

polated to the times of the ozone sonde launches. The CCM simulation used here consists of the last 17 years of a NIWAUKCA "REF-C1" simulation conducted for the ChemistryClimate Model Initiative (CCMI; Eyring et al., 2013). REFC1 is a hindcast simulation for the period of 1960-2010, using prescribed Hadley Centre Sea Ice and Sea Surface Temperature (HadISST) fields (Rayner et al., 2003). The surface emissions of primary species are as described in Eyring et al. (2013), ozone-depleting substances (ODSs) follow the A1 scenario of the WMO Report (WMO, 2011), and surface (or bulk, in the case of $\mathrm{CO}_{2}$ ) abundances of GHGs follow the "historical" Intergovernmental Panel on Climate Change scenario of global-mean GHG mixing ratios (Meinshausen et al., 2011).

In a "reference" simulation of the SCM all forcings are taken from this REF-C1 simulation of NIWA-UKCA. Alternatively, in sensitivity simulations $\mathrm{O}_{3}, \mathrm{H}_{2} \mathrm{O}, \mathrm{CH}_{4}, \mathrm{CO}$, and temperature, or all of these simultaneously, are replaced with the time series of the profiles that are constructed using longterm observational data as described above. For species other than those five fields, in all cases we use NIWA-UKCA REF$\mathrm{C} 1$ forcings. We evaluate the SCM only for those times, spaced roughly weekly, for which ozone sonde data are available. With the exceptions of those simulations assessing cloud influences, simulations are conducted assuming clearsky conditions.

\section{OH sensitivity to correcting chemistry-climate model biases}

In this section, we present sensitivity studies to assess the contribution of biases in known factors $\left(\mathrm{O}_{3}, \mathrm{H}_{2} \mathrm{O}, \mathrm{CH}_{4}, \mathrm{CO}\right.$, and temperature) affecting $\mathrm{OH}$ photochemistry at Lauder. 
The response of $\mathrm{OH}$ to changes in each forcing is assessed individually and also in combination.

\section{1 $\mathrm{OH}$ sensitivity to $\mathrm{O}_{3}$ biases}

Three sensitivity simulations are conducted to quantify the impact of $\mathrm{O}_{3}$ biases (defined as differences between observed $\mathrm{O}_{3}$ and NIWA-UKCA simulated $\mathrm{O}_{3}$ ) on $\mathrm{OH}$ at Lauder.

As discussed above, the rate of production $P$ of $\mathrm{HO}_{x}$ via $\mathrm{O}\left({ }^{1} \mathrm{D}\right)+\mathrm{H}_{2} \mathrm{O}$ can be expressed as

$P\left(\mathrm{HO}_{x}\right) \approx \frac{2 k_{1} j_{\mathrm{O}^{1} \mathrm{D}}\left[\mathrm{O}_{3}\right]\left[\mathrm{H}_{2} \mathrm{O}\right]}{k_{2}\left[\mathrm{O}_{2}\right]+k_{3}\left[\mathrm{~N}_{2}\right]+k_{1}\left[\mathrm{H}_{2} \mathrm{O}\right]}$,

where $k_{1}$ is the rate coefficient for $\mathrm{O}\left({ }^{1} \mathrm{D}\right)+\mathrm{H}_{2} \mathrm{O}, j_{\mathrm{O}^{1} \mathrm{D}}$ is the rate of $\mathrm{O}_{3}$ photolysis producing $\mathrm{O}\left({ }^{1} \mathrm{D}\right)$, and $k_{2}$ and $k_{3}$ are the rate coefficients of quenching of $\mathrm{O}\left({ }^{1} \mathrm{D}\right)$ with $\mathrm{O}_{2}$ and $\mathrm{N}_{2}$, respectively (Liu and Trainer, 1988; Thompson et al., 1989; Madronich and Granier, 1992; Fuglestvedt et al., 1994). Accordingly, $P\left(\mathrm{HO}_{x}\right)$ is affected by ozone changes principally in two different ways: Either locally through a change in $\left[\mathrm{O}_{3}\right]$ or non-locally through a change in $j_{\mathrm{O}^{1} \mathrm{D}}$ caused by changes in the overhead total-column ozone (TCO). To separate the effects, we conduct three simulations with the SCM: The first simulation targets the local kinetics effect by applying changes in $\mathrm{O}_{3}$ concentrations but keeping all photolysis rates unchanged vs. the reference simulation. A second simulation involves applying changes in $j_{\mathrm{O}^{1} \mathrm{D}}$ according to changes in $\mathrm{O}_{3}$ (keeping the rest of photolysis rates unchanged), but considering a fixed $\mathrm{O}_{3}$ concentration, i.e. using the $\mathrm{O}_{3}$ concentrations of the reference simulation. The $j_{\mathrm{O}^{1} \mathrm{D}}$ calculation consistently takes into account absorption and scattering by stratospheric and tropospheric $\mathrm{O}_{3}$. A third simulation includes both effects simultaneously.

The results of these three sensitivity runs are displayed in Fig. 3. As expected, the pattern of $\mathrm{O}_{3}$ differences between observed $\mathrm{O}_{3}$ and modelled $\mathrm{O}_{3}$ (Fig. 3a) is reflected in the pattern of $\mathrm{OH}$ differences produced by the SCM, considering only the "kinetics" effect and assuming no changes in the photolysis rates (Fig. 3b), with increases of ozone in spring and decreases in autumn, relative to the reference simulation, resulting in changes of the same sign in $\mathrm{OH}$. However, there is a height dependence to this relationship.

In summer and autumn, $\mathrm{O}_{3}$ biases range between -5 and $-45 \%$, meaning that the reference simulation overestimates the observations. Such a bias in $\mathrm{O}_{3}$ results in up to $12 \%$ reductions in $\mathrm{OH}$ for these seasons when the bias is corrected. In spring between 2 and $6 \mathrm{~km}$, observed $\mathrm{O}_{3}$ is larger than in the reference simulation by up to $10 \%$ at $4 \mathrm{~km}$ in October. Consequently, this results in an increase of $\mathrm{OH}$ at around the same altitudes and times of up to $5 \%$.

Regarding the sensitivity simulation considering the photolysis effects, $j_{\mathrm{O}^{1} \mathrm{D}}$ exhibits differences relative to the reference simulation ranging from $\sim 14$ to $\sim 30 \%$. The corrections are positive everywhere, in accordance with the overestimation of TCO in the NIWA-UKCA model with respect to observations (Morgenstern et al., 2013; Stone et al., 2016). In accordance with eq. 1 , such an intensification of $j_{\mathrm{O}^{1} \mathrm{D}}$ causes $\mathrm{OH}$ to increase (Fig. 3c). The relative $\mathrm{OH}$ response is approximately $50 \%$ of the $j_{\mathrm{O}^{1} \mathrm{D}}$ relative difference. However, Fig. $3 \mathrm{c}$ and $\mathrm{d}$ suggest that the magnitudes of the kinetics and the photolysis effects, for the $\mathrm{O}_{3}$ bias found at Lauder, are comparable, but the seasonalities differ. For example, the kinetics effect maximizes in spring at $5 \%$ and minimizes in summer/early autumn at $-15 \%$ (in the upper troposphere) whereas the photolysis effect on $\mathrm{OH}$ maximizes in summer at 16 to $20 \%$ and minimizes in spring (Fig. $3 \mathrm{~b}$ and d).

$\mathrm{OH}$ resulting from the combined kinetics and photolysis effects is displayed in Fig. 3e. $\mathrm{OH}$ responds approximately linearly to the two effects combined, compared to the sum of their individual impacts (Fig. 3f), despite some small differences between Fig. $3 e$ and $\mathrm{f}$.

Next, we examine the relationship between the slant column of $\mathrm{O}_{3}(\mathrm{SCO}), j_{\mathrm{O}^{1} \mathrm{D}}$, and $\mathrm{OH}$. Figure $4 \mathrm{a}$ shows that there is an approximately exponential relationship between $j_{\mathrm{O}^{1} \mathrm{D}}$ and the SCO at $6 \mathrm{~km}$ of altitude (this effect also exists at other altitudes). The small curvature may be the result of inaccurately diagnosing the SCO (ignoring the curvature of the Earth). Another reason could be that the cross section of $\mathrm{O}_{3}$ is wavelength-dependent, and consequently the actinic flux spectrum moves towards longer wavelengths with increasing SCO. Under Lambert-Beer's Law, a perfectly exponential relationship would be expected for a monochromatic UV light source and an isothermal atmosphere. $j_{\mathrm{O}^{1} \mathrm{D}}$ and the $\mathrm{OH}$ concentration exhibit an approximately linear relationship (Eq. 1, Fig. 4b). Combining these results, we derive an approximately exponential relationship between the SCO and the $\mathrm{OH}$ concentration (Fig. 4c). The fit parameters are stated in Fig. 4. Due to the compact relationship between $j_{\mathrm{O}^{1} \mathrm{D}}$ and the SCO, and to account for the curvature, we fit a quadratic relationship between the $\mathrm{SCO}$ and $\log \left(j_{\mathrm{O}^{1} \mathrm{D}}\right)$.

To determine a simple coefficient that describes the quantitative contribution of $\mathrm{O}_{3}$ to $\mathrm{OH}$, a linear regression between differences in $\mathrm{OH}$ and $\mathrm{O}_{3}$ relative to the reference was conducted through the following expression (note that this equation is also used to derive the linear contributions of the other key species to $\mathrm{OH}$ chemistry at Lauder):

$\frac{\Delta[\mathrm{OH}]}{[\mathrm{OH}]_{\mathrm{ref}}}=A_{i} \frac{\Delta X_{i}}{X_{i, \mathrm{ref}}}$,

where $X_{i}$ is the perturbation variable (in this case $\left[\mathrm{O}_{3}\right]$ ), $A_{i}$ is the slope of the linear regression, $\Delta[\mathrm{OH}]$ is the absolute difference between the $\mathrm{OH}$ concentrations in the reference and perturbation simulations, $\Delta X$ is the absolute difference in concentrations of the perturbation variable $X$ between the observations and the reference, $[\mathrm{OH}]_{\text {ref }}$ is the $\mathrm{OH}$ concentration obtained from the reference simulation, and $X_{i \text {,ref }}$ is the value of $X_{i}$ in the reference simulation. The regression coefficients $A_{i}$ represent the sensitivity of $\mathrm{OH}$ to changes in each individual variable for the troposphere at Lauder. The regression coefficients are depicted in Fig. 5. Reverting to 
(a)

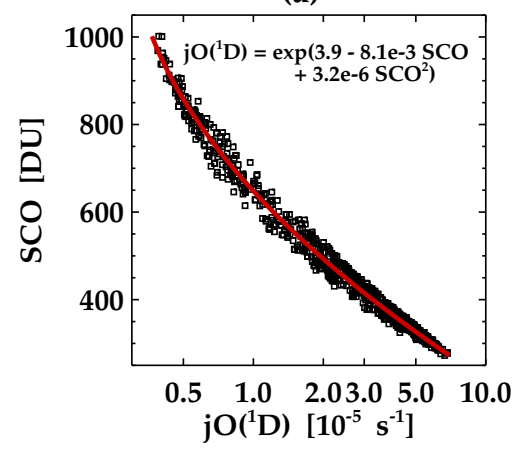

(b)

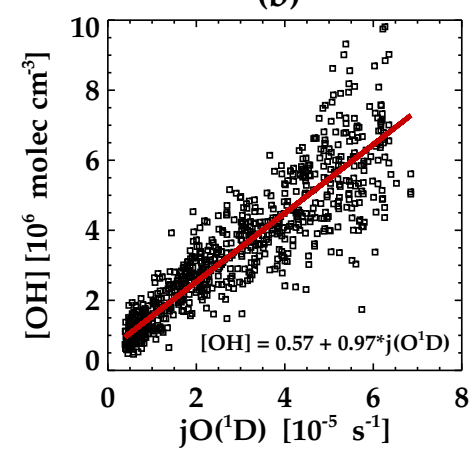

(c)

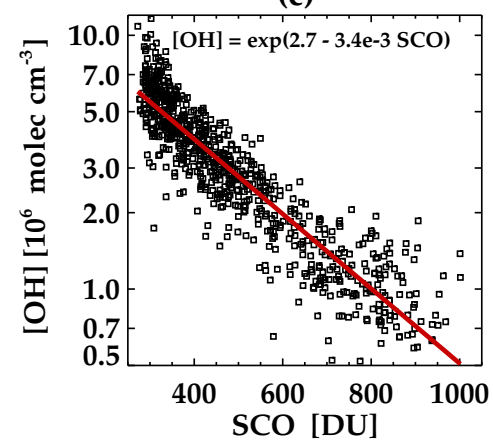

Figure 4. (a) Scatter plot of $j_{\mathrm{O}^{1} \mathrm{D}}$ with the slant column of $\mathrm{O}_{3}$ (SCO) at $6 \mathrm{~km}$ of altitude. (b) Same, but for $j_{\mathrm{O}^{1} \mathrm{D}}$ and OH. (c) Same, but for the $\mathrm{SCO}$ and $\mathrm{OH}$. The results shown in this figure are those obtained from the combined simulation (kinetics and photolysis effects). Red lines denote least-squares fits between the variable pairs. The best fits are stated in the panels, with $[\mathrm{OH}]$ in units of $10^{6} \mathrm{~mol} \mathrm{~cm}^{-3}, j_{\mathrm{O}^{1} \mathrm{D}}$ in units of $10^{-5} \mathrm{~s}^{-1}$, and the SCO in Dobson Units.

infinitesimal notation, we note that

$A_{i}=\frac{\partial \ln [\mathrm{OH}]}{\partial \ln X_{i}}$.

The sensitivity coefficients of $\mathrm{OH}$ to the kinetics and photolysis effects of $\mathrm{O}_{3}$ are shown in Fig. 5a. Coefficient $A_{1}$, which represent the kinetics effect, ranges from 0 to 0.25 (meaning the relative response of $\mathrm{OH}$ is up to a quarter of the relative difference in $\mathrm{O}_{3}$ ). The sensitivity to photolysis
$\left(A_{1}^{\prime \prime}\right)$ is $>0.5$ throughout much of the troposphere (meaning the relative response in $\mathrm{OH}$ is over half the relative change in $\left.j_{\mathrm{O}^{1} \mathrm{D}}\right)$.

\section{2 $\mathrm{OH}$ sensitivity to $\mathrm{H}_{2} \mathrm{O}$ biases}

A perturbation simulation was performed using combined radiosonde and NIWA-UKCA $\mathrm{H}_{2} \mathrm{O}$ (Sect. 2.2). The $\mathrm{OH}$ response to correcting $\mathrm{H}_{2} \mathrm{O}$ biases (Fig. 6) shows an approximately linear response with respect to the relative changes in $\mathrm{H}_{2} \mathrm{O}$, i.e. decreases in $\mathrm{H}_{2} \mathrm{O}$ generally lead to a reduction of $\mathrm{OH}$ concentrations (Eq. 1). Note that NIWA-UKCA substantially overestimates the radiosonde-observed $\mathrm{H}_{2} \mathrm{O}$ vapour by up to $60 \%$ between 2 and $6 \mathrm{~km}$ (Fig. 6a); this translates into an overestimation of $\mathrm{OH}$ by up to $\sim 40 \%$ in the reference simulation (Fig. 6c) in the same region. The sensitivity of $\mathrm{OH}$ to changes in $\mathrm{H}_{2} \mathrm{O}$ (Eq. 2) range from 5 to 0.5 in the troposphere (Figs. $6 \mathrm{e}$ and $5 \mathrm{~b}$ coefficient $A_{2}$ ), with high sensitivity in the lower and free troposphere and reduced sensitivity in the tropopause region.

It is known that large uncertainties are associated with $\mathrm{H}_{2} \mathrm{O}$ vapour measurements. To illustrate this, we repeat the above simulation but now using European Centre for Medium-Range Weather Forecasts (ECMWF) ERA-Interim reanalysis (hereafter ERAI) $\mathrm{H}_{2} \mathrm{O}$ (Dee et al., 2011). Irrespectively of the large differences and the opposite signs in $\mathrm{H}_{2} \mathrm{O}$ biases between Lauder radiosonde and ERAI data, the $\mathrm{OH}$ response to biases in $\mathrm{H}_{2} \mathrm{O}$ shows approximately the same linear relationship in both cases (Fig. 6). Likewise, the sensitivity of $\mathrm{OH}$ to changes in $\mathrm{H}_{2} \mathrm{O}$ using ERAI data (Figs. 6f and $5 \mathrm{~b}$, coefficient $A_{3}$ ) resembles the sensitivity simulation using radiosonde $\mathrm{H}_{2} \mathrm{O}$.

\subsection{OH sensitivity to $\mathrm{CH}_{4}$ and $\mathrm{CO}$ biases}

The effect of $\mathrm{CH}_{4}$ changes on $\mathrm{OH}$ is displayed in Fig. 7a, c, e. The $\mathrm{CH}_{4}$ biases are generally small, up to only $\sim 2 \%$, and are assumed to be vertically uniform, with some seasonal variations. Decreases in $\mathrm{CH}_{4}$ lead to increases in $\mathrm{OH}$ due to reduced loss of $\mathrm{HO}_{x}$ by $\mathrm{CH}_{4}+\mathrm{OH}$. The response of $\mathrm{OH}$ to $\mathrm{CH}_{4}$ changes maximizes at $0.6 \%$ around $2 \mathrm{~km}$, and decreases at higher altitudes. The seasonal variation of the $\mathrm{OH}$ response to $\mathrm{CH}_{4}$ biases maximizes in March/April (Fig. 7c), which coincides with the maximum absolute bias in $\mathrm{CH}_{4}$ (Fig. 7a) in the same months. The sensitivity coefficient describing the dependence of $\mathrm{OH}$ on $\mathrm{CH}_{4}$ changes (denoted as $A_{4}$ in Fig. 5c) ranges from -0.17 at the surface to -0.32 at $\sim 2 \mathrm{~km}$ of altitude, and then decreases to -0.15 at $10 \mathrm{~km}$.

The $\mathrm{CO}$ bias and the resulting differences in $\mathrm{OH}$ are displayed in Fig. 7b, d, f. The relative difference of $\mathrm{OH}$ with respect to the reference simulation is less than $\pm 5 \%$ for all seasons (Fig. 7d), showing that decreases in $\mathrm{CO}$ generally lead to increases in $\mathrm{OH}$ through the reduced loss of $\mathrm{OH}$ through $\mathrm{OH}+\mathrm{CO}$. Note that during austral spring NIWA-UKCA overestimates $\mathrm{CO}$, presumably due to exaggerated tropical 

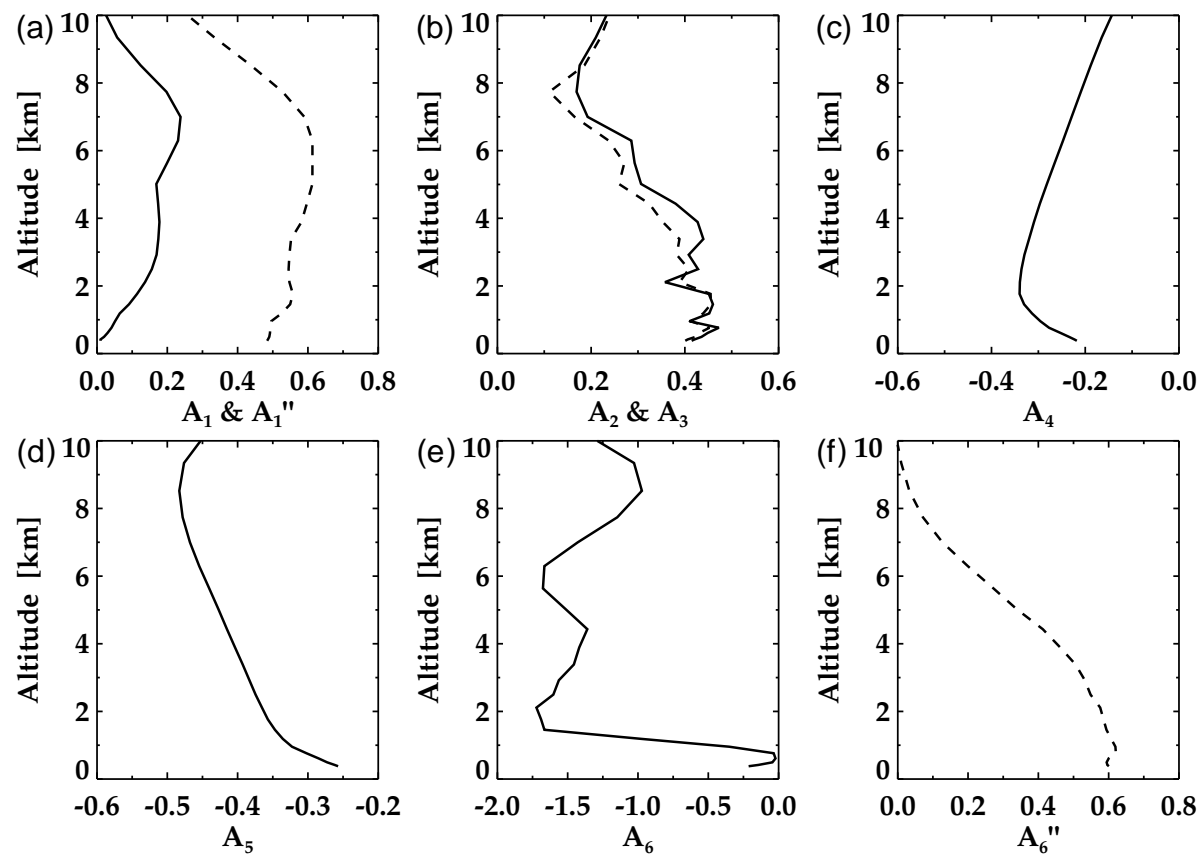

Figure 5. Sensitivity coefficients $A_{i}^{\prime \prime}$ between $\mathrm{OH}$ and each perturbation variable: In the calculation, multi-annual mean relative differences in $\mathrm{OH}$ and in the forcing are ratioed. (a) Sensitivity of $\mathrm{OH}$ to changes in $\mathrm{O}_{3}$ levels (kinetics effect) denoted by $A_{1}$ (solid line) and to changes in $j_{\mathrm{O}^{1} \mathrm{D}}$ due to changes in $\mathrm{O}_{3}$ (photolysis effect) denoted by $A_{1}^{\prime \prime}$ (dashed line); (b) sensitivity of OH to changes in radiosonde - NIWA-UKCA $\mathrm{CCM} \mathrm{H} \mathrm{H}_{2} \mathrm{O}\left(A_{2}\right.$ solid line) and to changes in ERAI - NIWA-UKCA $\mathrm{H}_{2} \mathrm{O}\left(A_{3}\right.$ dashed line); (c) sensitivity of $\mathrm{OH}$ to changes in $\mathrm{CH}_{4}\left(A_{4}\right)$; (d) sensitivity of $\mathrm{OH}$ to changes in $\mathrm{CO}\left(A_{5}\right)$; (e) sensitivity of $\mathrm{OH}$ to changes in temperature (kinetics effect) denoted by $A_{6}$; (f) sensitivity of $\mathrm{OH}$ to changes in $j_{\mathrm{O}^{1} \mathrm{D}}$ due to changes in temperature (photolysis effect) denoted by $A_{6}^{\prime \prime}$.

biomass burning in the model which causes $\mathrm{CO}$ biases of up to $10 \%$ (Fig. 7b). The sensitivity of $\mathrm{OH}$ to changes in $\mathrm{CO}$ $(\partial \ln [\mathrm{OH}] / \partial \ln [\mathrm{CO}])$ shown in Fig. $7 \mathrm{f}$ varies from -0.3 to -0.5 and in absolute terms increases with altitude (the white band shown in October is the result of $\mathrm{CO}$ differences being close to zero).

The sensitivities of $\mathrm{OH}$ to $\mathrm{CH}_{4}$ and $\mathrm{CO}$ show comparable values at the surface, but the $\mathrm{OH}$ sensitivity to $\mathrm{CO}$ increases with height whereas its sensitivity to $\mathrm{CH}_{4}$ decreases. Note that the $\mathrm{CH}_{4}+\mathrm{OH}$ reaction rate is strongly temperaturedependent, which may contribute to the lower sensitivity of $\mathrm{OH}$ to $\mathrm{CH}_{4}$ changes at altitude than to $\mathrm{CO}$. However, further investigation will need to investigate how these ratios change in different chemical regimes, and to assess whether the relative sensitivity of $\mathrm{OH}$ to $\mathrm{CO}$ and to $\mathrm{CH}_{4}$ are specific to the clean SH environment.

\subsection{OH sensitivity to temperature biases}

To assess the effects of changes in temperature on $\mathrm{OH}$, we apply the same procedure as for $\mathrm{O}_{3}$, for which the effects of temperature have been decomposed into kinetics and photolysis effects. We perform three simulations: In the first simulation, we only apply temperature changes to chemical kinetics, keeping all photolysis rates fixed (noting that most uni-, bi-, and termolecular reaction rates are temperature- dependent). In the second simulation, we only consider the photolysis effect, which arises mainly because the cross section of $\mathrm{O}_{3}$, the primary UV absorber, is temperaturedependent. The impact of temperature on $\mathrm{OH}$ via ozone photolysis again occurs via two different mechanisms: firstly, the changes in $j_{\mathrm{O}^{1} \mathrm{D}}$ caused by changes in the actinic flux which relates to changes in the atmospheric transmissivity in the UV (caused by a temperature dependence of the cross section of overhead ozone), and the local changes of $j_{\mathrm{O}^{1} \mathrm{D}}$, due to the local temperature dependence of the ozone cross section. Here, we only evaluate the combined photolysis effect in the second simulation. Finally, we perform a third simulation by applying both the kinetics and the photolysis effects simultaneously.

At Lauder, the reference simulation is generally coldbiased (i.e. the temperature correction is positive; Fig. 8a). This is particularly the case in the lowest $2 \mathrm{~km}$ and throughout the troposphere in the autumn-winter season. The kinetics effect leads to a reduction of $\mathrm{OH}$ by up to $2 \%$ (Fig. $8 \mathrm{~b}$ ). $\mathrm{O}\left({ }^{1} \mathrm{D}\right)+\mathrm{H}_{2} \mathrm{O}$ and the quenching reactions (Eq. 1) are not, or are weakly, temperature-dependent, making $\mathrm{CH}_{4}+\mathrm{OH}$ (which is much more sensitive to temperature) the leading factor in causing this small $\mathrm{OH}$ reduction. The rate coefficient for this reaction in NIWA-UKCA and the SCM is $k_{\mathrm{OH}}+\mathrm{CH}_{4}=1.85 \times 10^{-12} \exp (-1690 \mathrm{~K} / T)$; at $290 \mathrm{~K}$ the sensitivity of $k_{\mathrm{OH}}+\mathrm{CH}_{4}$ to temperature changes evaluates to 
(a) $\mathrm{H}_{2} \mathrm{O}$ biases using radiosonde $\mathrm{H}_{2} \mathrm{O}$

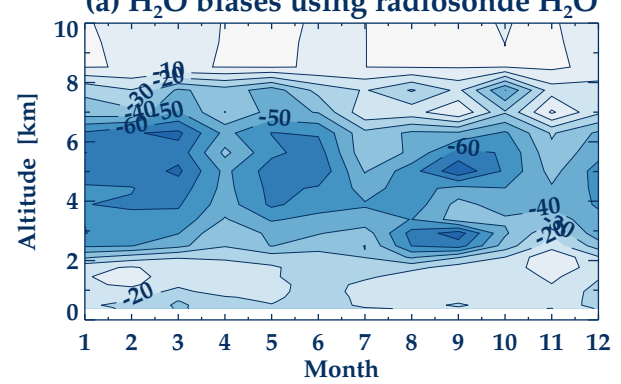

(c) $\mathrm{OH}$ response to $\mathrm{H}_{2} \mathrm{O}$ (radiosonde)

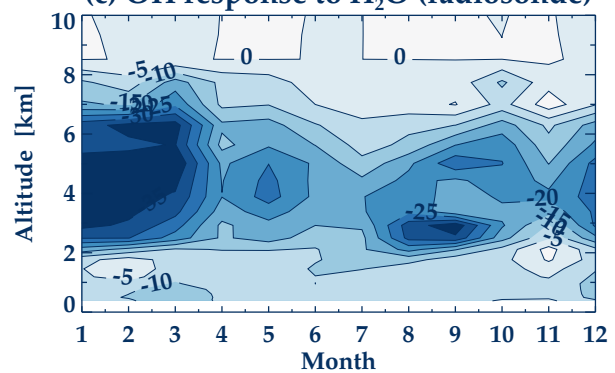

(e) $\mathrm{OH}$ sensitivity to $\mathrm{H}_{2} \mathrm{O}$ (radiosonde)

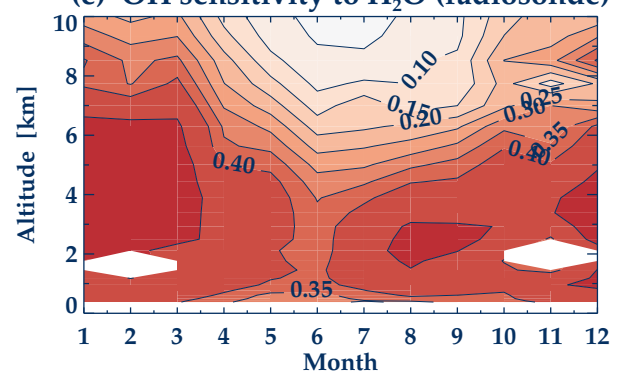

(b) $\mathrm{H}_{2} \mathrm{O}$ biases using ERAI $\mathrm{H}_{2} \mathrm{O}$

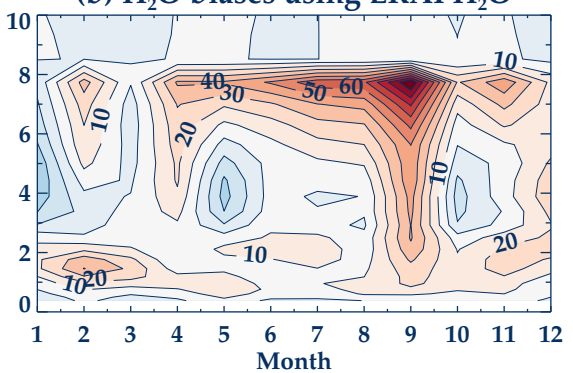

(d) $\mathrm{OH}$ response to $\mathrm{H}_{2} \mathrm{O}$ (ERAI)

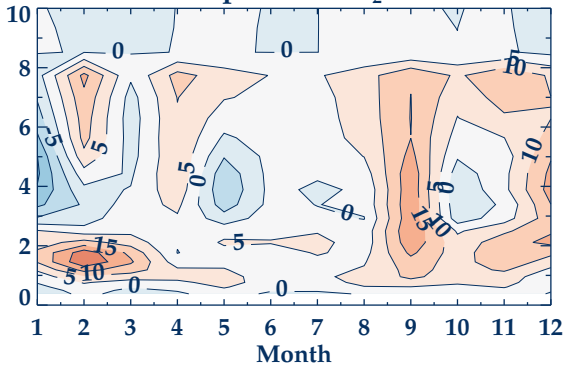

(f) $\mathrm{OH}$ sensitivity to $\mathrm{H}_{2} \mathrm{O}$ (ERAI)

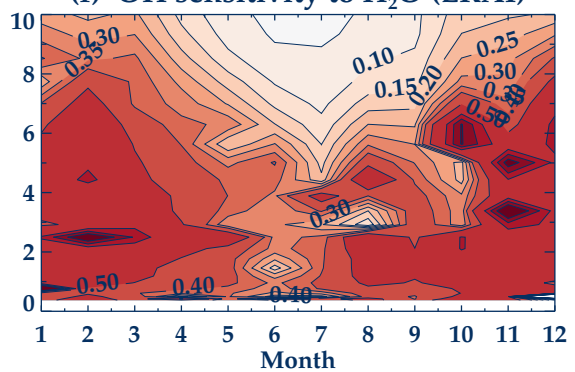

Figure 6. Multi-annual and monthly-mean $\mathrm{OH}$ responses to $\mathrm{H}_{2} \mathrm{O}$ between perturbation simulations and the reference simulation. (a) Radiosonde - NIWA-UKCA $\mathrm{H}_{2} \mathrm{O}(\%)$ relative to the reference simulation. (b) ERAI - NIWA-UKCA $\mathrm{H}_{2} \mathrm{O}(\%)$ relative to the reference simulation. (c) $\mathrm{OH}$ difference (\%) relative to the reference simulation between simulations using radiosonde and NIWA-UKCA $\mathrm{H}_{2} \mathrm{O}$ (a). (d) $\mathrm{OH}$ differences (\%) relative to the reference simulation between simulations using ERAI and NIWA-UKCA CCM H $2 \mathrm{O}(\mathbf{b})$. (e) Ratio of relative $\mathrm{OH}$ changes (c) to relative changes in $\mathrm{H}_{2} \mathrm{O}$ (a). (f) Ratio of relative $\mathrm{OH}$ changes (d) to changes in $\mathrm{H}_{2} \mathrm{O}$ (b). Above 8 km NIWA-UKCA $\mathrm{H}_{2} \mathrm{O}$ was used in both cases. Therefore, differences with respect to the reference simulation are close to 0 .

about $2 \% \mathrm{~K}^{-1}$. However, $\mathrm{OH}$ is well buffered by other reactions, so its sensitivity is considerably smaller than that. The photolysis effect is often somewhat larger than the kinetics effect but peaks in spring (Fig. 8c). This translates into a slight $\mathrm{OH}$ reduction comparable in magnitude to the kinetics effect (Fig. 8d). Both effects add nearly linearly in the combined simulation (Fig. 8e, f).

We calculate sensitivity coefficients $A_{6}$ and $A_{6}^{\prime \prime}$ that define the $\mathrm{OH}$ responses to both effects (Fig. 5e, f). Coefficient $A_{6}$ represents the kinetics effect and varies from 0 to -1.75 (i.e. in absolute terms, the relative $\mathrm{OH}$ response can be larger than the relative difference in $T$ ). The sensitivity coefficient that describes the sensitivity of $\mathrm{OH}$ to changes in photolysis $\left(A_{6}^{\prime \prime}\right)$ ranges from 0.6 at the surface to 0 at $10 \mathrm{~km}$ of altitude. Figure $5 \mathrm{e}$ and $\mathrm{f}$ show sensitivity coefficients for both effects $\left(A_{6}\right.$ and $A_{6}^{\prime \prime}$ ). $\mathrm{OH}$ changes due to both effects are small (up to $2.5 \%)$ and comparable in magnitude.
Several sensitivity studies have been conducted previously to elucidate the impact of temperature on $\mathrm{OH}$ (Stevenson et al., 2000; Wild, 2007; O'Connor et al., 2009). None of these studies separately assessed the impacts of the kinetics and photolysis effects of temperature on $\mathrm{OH}$. Wild (2007) applied a globally uniform temperature rise of $5 \mathrm{~K}$ that led to a larger $\mathrm{OH}$ abundance and an around $10 \%$ decrease in the $\mathrm{CH}_{4}$ lifetime. O'Connor et al. (2009) showed a small impact on global $\mathrm{OH}$ abundances due to temperature biases; this may be because either the temperature biases in their model were both positive and negative, in different regions, leading to some cancellation of the impact on global $\mathrm{OH}$, or to low $\mathrm{OH}$ sensitivity to temperature biases. Here, bias-correcting temperature is shown to also have only a small impact on $\mathrm{OH}$ abundance (Fig. 8e); this result broadly corroborates that of O'Connor et al. (2009). 
(a) $\mathrm{CH}_{4}$ biases

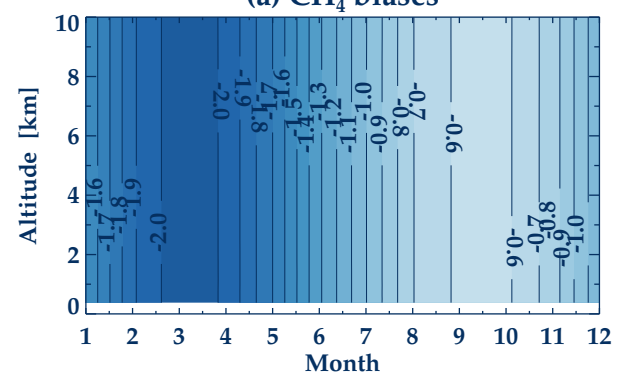

(c) $\mathrm{OH}$ response to $\mathrm{CH}_{4}$

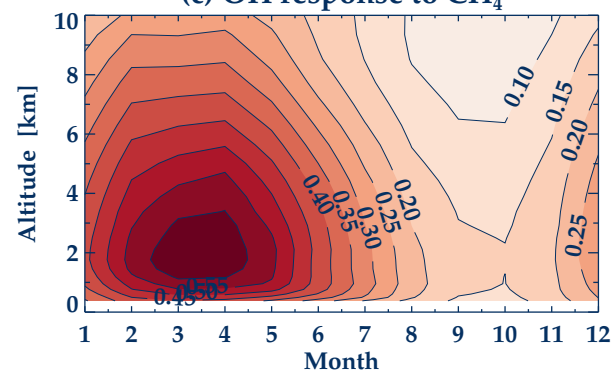

(e) $\mathrm{OH}$ sensitivity to $\mathrm{CH}_{4}$

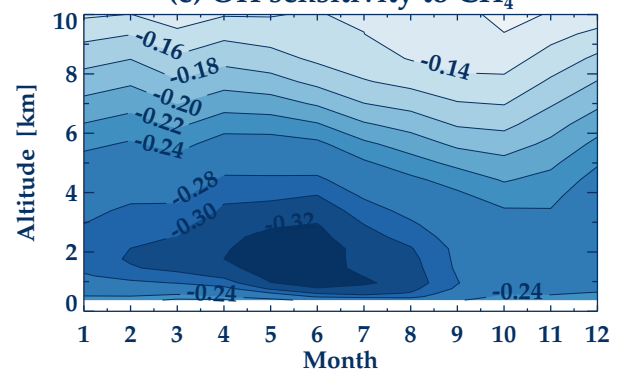

(b) CO biases

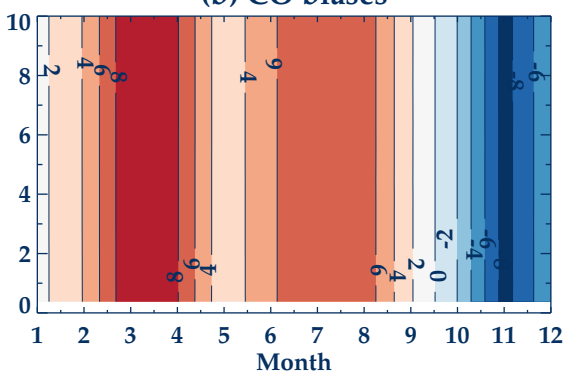

(d) $\mathrm{OH}$ response to $\mathrm{CO}$

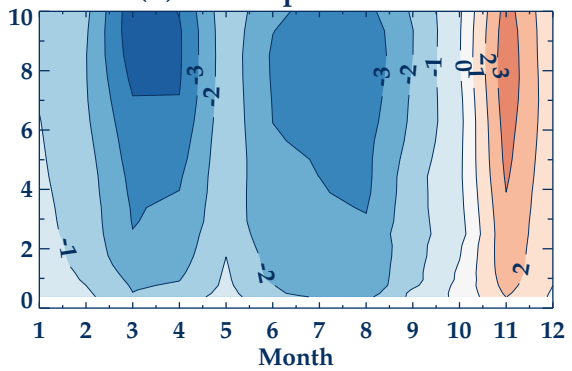

(f) $\mathrm{OH}$ sensitivity to $\mathrm{CO}$

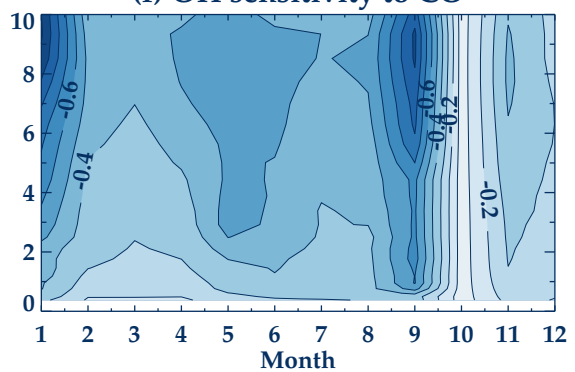

Figure 7. Multi-annual and monthly-mean $\mathrm{OH}$ responses to $\mathrm{CH}_{4}$ and $\mathrm{CO}$ biases between observations and the reference simulation. (a) Difference in $\mathrm{CH}_{4}(\%)$ relative to the reference simulation. (b) Difference in $\mathrm{CO}(\%)$ relative to the reference simulation. (c) OH difference (\%) relative to the reference simulation caused by the $\mathrm{CH}_{4}$ change (a). (d) $\mathrm{OH}$ difference (\%) relative to the reference simulation caused by the $\mathrm{CO}$ change (b). (d) Ratio of relative $\mathrm{OH}$ changes (c) to relative changes in $\mathrm{CH}_{4}$ (a). (f) Ratio of relative $\mathrm{OH}$ changes (d) to relative changes in $\mathrm{CO}(\mathbf{b})$.

\subsection{Linearity of $\mathrm{OH}$ sensitivity to biases in all forcings}

Here, we assess the effect of changing all forcings $\left(\mathrm{O}_{3}\right.$, $\mathrm{H}_{2} \mathrm{O}, \mathrm{CH}_{4}, \mathrm{CO}$, and temperature) simultaneously on $\mathrm{OH}$ at Lauder. Figure $9 \mathrm{a}$ shows the responses of $\mathrm{OH}$ to changing all forcings. A comparison with Fig. 6 suggests that $\mathrm{H}_{2} \mathrm{O}$ changes dominate the total response of $\mathrm{OH}$ to changes in these forcings. At Lauder, NIWA-UKCA is too moist (relative to radiosonde water vapour); this translates into a large $\mathrm{OH}$ overestimation of up to $\sim 40 \%$ in the reference simulation (Fig. 9a). This is consistent with the underestimated $\mathrm{CH}_{4}$ lifetime by the NIWA-UKCA model (Morgenstern et al., 2013; Telford et al., 2013), assuming that the NIWA-UKCA model is also too moist in other regions. (In the NIWAUKCA reference simulation used here, the global $\mathrm{CH}_{4}$ lifetime, disregarding dry deposition, is 7.2 years, whereas a recent best estimate is 9.8 years, with an uncertainty range of 7.6-14 years; SPARC, 2013.) In general, in the SCM OH re- sponds approximately linearly to the combined changes in major forcings that play an important role in $\mathrm{OH}$ chemistry (Fig. 9).

To examine the linearity of $\mathrm{OH}$ responses to simultaneous changes in key forcings defined in this study, the combination of all individual contributions, i.e. $\mathrm{O}_{3}$ (kinetics and photolysis effects), $\mathrm{H}_{2} \mathrm{O}, \mathrm{CH}_{4}, \mathrm{CO}$, and temperature (kinetics and photolysis effects) to $\mathrm{OH}$, was compared to the $\mathrm{OH}$ response to all forcings combined simulation in the SCM through Eq. (4):

$$
\begin{aligned}
\frac{\Delta[\mathrm{OH}]}{[\mathrm{OH}]_{\mathrm{ref}}} \approx & A_{1}^{\prime \prime} \frac{\Delta\left[\mathrm{O}_{3}\right]}{\left[\mathrm{O}_{3}\right]_{\mathrm{ref}}}+A_{1}^{\prime \prime} \frac{\Delta j_{\mathrm{O}^{1} \mathrm{D}_{\mathrm{O}_{3}}}}{j_{\mathrm{O}^{1} \mathrm{D}_{\mathrm{ref}}}}+A_{2} \frac{\Delta\left[\mathrm{H}_{2} \mathrm{O}\right]}{\left[\mathrm{H}_{2} \mathrm{O}\right]_{\mathrm{ref}}} \\
& +A_{4} \frac{\Delta\left[\mathrm{CH}_{4}\right]}{\left[\mathrm{CH}_{4}\right]_{\mathrm{ref}}}+A_{5} \frac{\Delta[\mathrm{CO}]}{[\mathrm{CO}]_{\mathrm{ref}}} \\
& +A_{6} \frac{\Delta T}{T_{\mathrm{ref}}}+A_{6}^{\prime \prime} \frac{\Delta j_{\mathrm{O}^{1} \mathrm{D}_{\mathrm{T}}}}{j_{\mathrm{O}^{1} \mathrm{D}_{\mathrm{ref}}}}
\end{aligned}
$$


(a) Temperature biases

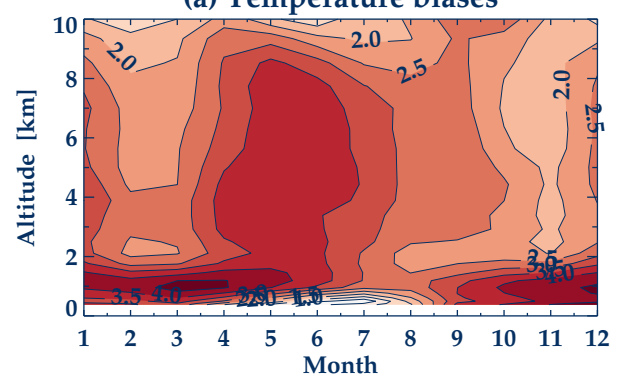

(c) $\mathrm{jO}\left({ }^{1} \mathrm{D}\right)$ biases

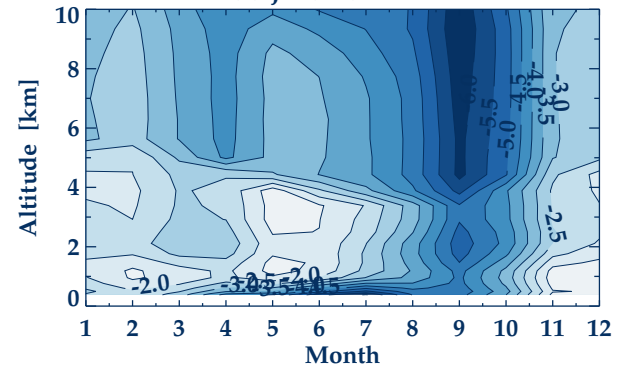

(e) $\mathrm{OH}$ response to photolysis and kinetics

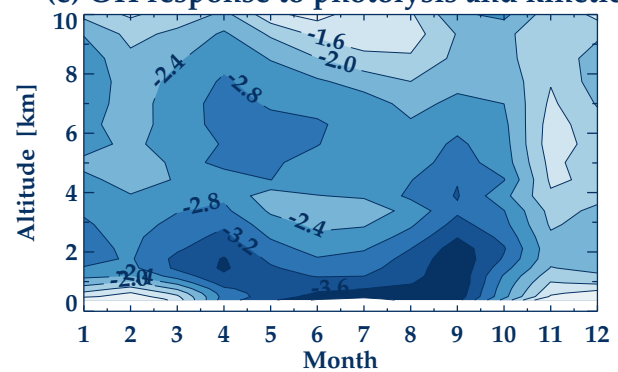

(b) $\mathrm{OH}$ response to kinetics

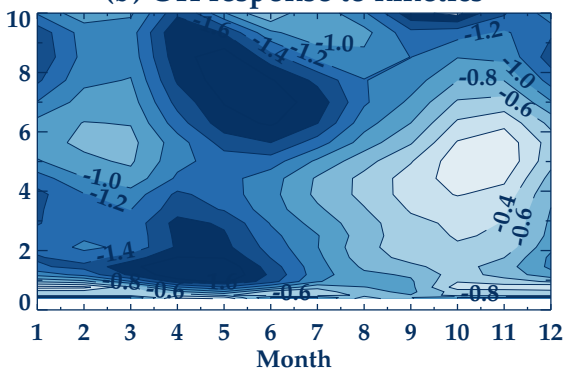

(d) $\mathrm{OH}$ response to photolysis

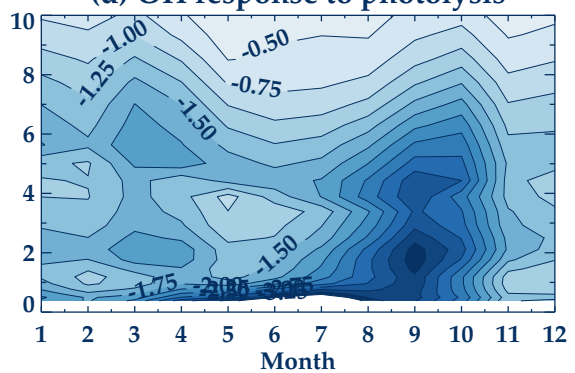

(f) Result of summing (b) and (d)

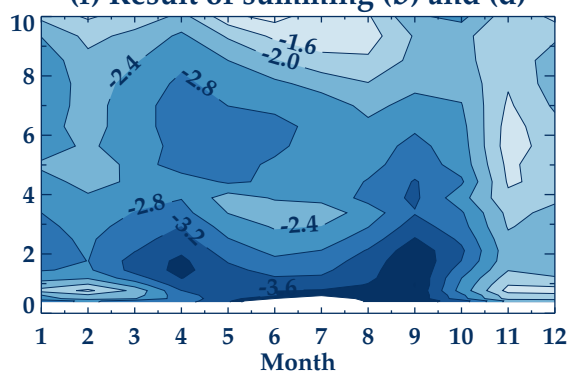

Figure 8. Multi-annual and monthly-mean $\mathrm{OH}$ responses to temperature biases between observations (radiosonde and NCEP/NCAR temperature) and the reference simulation. (a) Difference in radiosonde and NCEP/NCAR temperature (K) relative to the reference temperature. (b) $\mathrm{OH}$ difference $(\%)$ relative to the reference simulation accounting only for the kinetics effects of temperature differences (e.g. with $j_{\mathrm{O}^{1} \mathrm{D}}$ unchanged). (c) Difference in $j_{\mathrm{O}^{1} \mathrm{D}}(\%)$ relative to the reference simulation. (d) $\mathrm{OH}$ difference $(\%)$ relative to the reference simulation accounting only for $j_{\mathrm{O}^{1} \mathrm{D}}$ differences (i.e. with temperature unchanged). (e) $\mathrm{OH}$ differences relative to the reference simulation considering the combined kinetics and photolysis effects. (f) Sum of (b) and (d).

where $\Delta[\mathrm{OH}] /[\mathrm{OH}]_{\mathrm{ref}}$ is the relative difference in the $\mathrm{OH}$ concentration obtained with the SCM with respect to the reference simulation, using all forcings combined. The forcings comprise the kinetics and photolysis effects of $\mathrm{O}_{3}\left(A_{1}\right.$ and $\left.A_{1}^{\prime \prime}\right)$, radiosonde $\mathrm{H}_{2} \mathrm{O}\left(A_{2}\right), \mathrm{CH}_{4}\left(A_{4}\right), \mathrm{CO}\left(A_{5}\right)$, and the kinetics and photolysis effects of temperature ( $A_{6}$ and $\left.A_{6}^{\prime \prime}\right)$. Equation (4) expresses a working hypothesis that the model responds linearly to the applied forcings; we will test this assumption in the following paragraph.

Figure $9 \mathrm{a}$ and $\mathrm{b}$ indicate that the model responds approximately linearly to the combinations of all forcings, with $\mathrm{OH}$ responses in the all-forcings simulation correlating at 0.9 with the sum of the $\mathrm{OH}$ responses in the individualforcing simulations. Figure 9c however also suggests that there is some notable non-linearity in the chemistry of the troposphere at Lauder. Chemical feedbacks between the impacts of correcting water vapour and ozone may contribute to this non-linearity; for example, a change in the water vapour abundance may impact the sensitivity of $\mathrm{OH}$ to changing $\mathrm{O}_{3}$.

\subsection{Trends in $\mathrm{OH}$}

We examine variability and trends in $\mathrm{OH}$ using the SCM simulation including all key forcings separately for different altitude bins. The results (Fig. 10) indicate that there are no significant long-term trends in $\mathrm{OH}$ throughout the troposphere for the period of the simulation (1994-2010) We find trends of $-2.1 \pm 4.8 \%$ at $0-2.5 \mathrm{~km}, 0.9 \pm 2.3 \%$ at $2.5-5 \mathrm{~km}$, $2.6 \pm 3.5 \%$ at $5-7.5 \mathrm{~km}$, and $3.6 \pm 4.1 \%$ at $7.5-10 \mathrm{~km}$ over the period of 1994-2010), but there is evidence of interannual variations at all altitudes (e.g. Manning et al., 2005; Montzka et al., 2011).

In addition, we explore variability and trends in the $\mathrm{OH}$ column at Lauder to be compared with other estimates of 

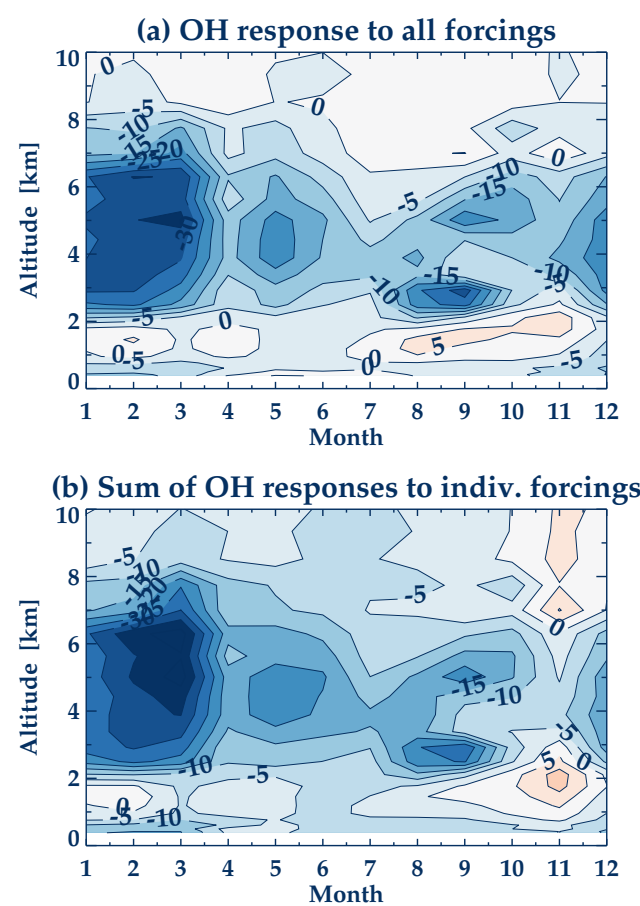

(c) Scatter plot of (a) versus (b)

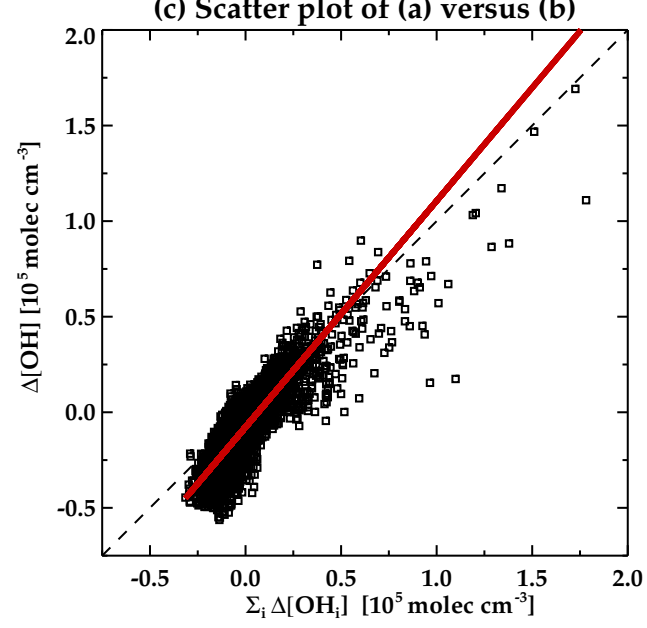

Figure 9. (a) Multi-annual and monthly-mean percentage difference in $\mathrm{OH}$ between a simulation with bias correction applied to all five fields and the reference simulation. Radiosonde $\mathrm{H}_{2} \mathrm{O}$ is assumed below $8 \mathrm{~km}$. (b) Summation of all the single forcing contributions as expressed by the right hand side of Eq. (4). Radiosonde $\mathrm{H}_{2} \mathrm{O}$ is assumed below $8 \mathrm{~km}$. (c) Scatter plot of the response of $\mathrm{OH}$ to the combination of all forcings (vertical axis, denoted as $\Delta[\mathrm{OH}]$ ) vs. the summation of the $\mathrm{OH}$ response to individual forcings (horizontal axis) as expressed by the right hand side of Eq. (4) (denoted by $\left.\sum_{i} \Delta\left[\mathrm{OH}_{i}\right]\right)$. The red solid line denotes an orthogonal fit. The black dashed line is the diagonal.

global $\mathrm{OH}$. As expected from the results of $\mathrm{OH}$ trends at different altitude bins, we find no significant long-term trend in the $\mathrm{OH}$ column $(0.5 \pm 1.3 \%)$ (Fig. 11). However, there is evidence of short-term variations (5-10\%), in agreement with other studies that used observations to infer global $\mathrm{OH}$ concentrations (e.g. Manning et al., 2005; Montzka et al., 2011).

\subsection{OH sensitivity to the presence of clouds}

We have assessed the $\mathrm{OH}$ sensitivity to correcting biases in key forcings assuming clear skies. Here we explore the impact of simulated clouds on $\mathrm{OH}$, recognizing that this process is associated with large uncertainties due to difficulties with representing clouds in models. Measurements of cloud profiles do not exist at Lauder, hence a bias correction like that performed with the composition and temperature fields is not possible. Therefore, here we only examine the impact of clouds simulated by NIWA-UKCA on $j_{\mathrm{O}^{1} \mathrm{D}}$ and $\mathrm{OH}$ at Lauder, relative to the clear-sky reference simulation used before. The impacts of liquid water clouds (LWCs) and ice clouds (ICs) were assessed separately and in combination. Three simulations are defined here, i.e. (1) including only ICs, (2) including only LWCs, and (3) considering both combined (LICs).

Figure 12a, c and e show the response of $j_{\mathrm{O}^{1} \mathrm{D}}$ and $\mathrm{OH}$ to the presence of the ICs. $j_{\mathrm{O}^{1} \mathrm{D}}$ and $\mathrm{OH}$ are generally reduced below the ICs, relative to the cloud-free situation. The maximum reduction in $\mathrm{OH}$ is 10 to $15 \%$ in winter below $2 \mathrm{~km}$, coinciding with the maximum reduction in $j_{\mathrm{O}^{1} \mathrm{D}}$. There are increases in both fields (up to $\sim 8 \%$ ) above the ICs in austral spring, associated with the seasonal peak in IC occurrence at the same time. In general, $j_{\mathrm{O}^{1} \mathrm{D}}$ and $\mathrm{OH}$ impacts vary strongly with season, with the maximum reduction occurring in winter close to the surface, and the maximum increase in spring above the ICs.

LWCs are mostly present between 1 and $4 \mathrm{~km}$ with the seasonal peak in austral spring (Fig. 12b). Similarly to ICs, $j_{\mathrm{O}^{1} \mathrm{D}}$ and $\mathrm{OH}$ are enhanced above and throughout much of the cloud layer, and reduced in the lowest $1 \mathrm{~km}$ above the surface (Fig. 12e, g). The enhancement in $j_{\mathrm{O}^{1} \mathrm{D}}$ and $\mathrm{OH}$ peaks at $12 \%$ between 2 and $4 \mathrm{~km}$ of altitude, coinciding with the spring maximum in liquid water content at $1-2 \mathrm{~km}$. Conversely, the reduction in $j_{\mathrm{O}^{1} \mathrm{D}}$ and $\mathrm{OH}$ with respect to the clear-sky condition is $\sim 10 \%$ and is produced below the clouds.

The simulation with the combined effect of ICs and LWCs (LICs) produces a reduction in $j_{\mathrm{O}^{1} \mathrm{D}}$ and $\mathrm{OH}$ that ranges between 0 and $20 \%$ below the transition of ICs to LWCs at around $2 \mathrm{~km}$, since LWCs are as much as twice as optically dense as ICs (Fig. 12g). An enhancement is produced above this altitude of up to $18 \%$. The magnitudes of changes in $j_{\mathrm{O}^{1} \mathrm{D}}$ and $\mathrm{OH}$ are similar when either ICs or LWCs are considered in the SCM. Furthermore, their effects add up slightly less than linearly when both are present in the simulations (Fig. 12h).

The results shown here indicate that lower clouds generally produce an enhancement in $j_{\mathrm{O}^{1} \mathrm{D}}$ (Fig. 12d), but higher clouds generally produce a reduction in $j_{\mathrm{O}^{1} \mathrm{D}}$ in the free troposphere (Fig. 12b; Tang et al., 2003; Tie et al., 2003; Liu et al., 2009). Furthermore, the vertically and seasonally av- 

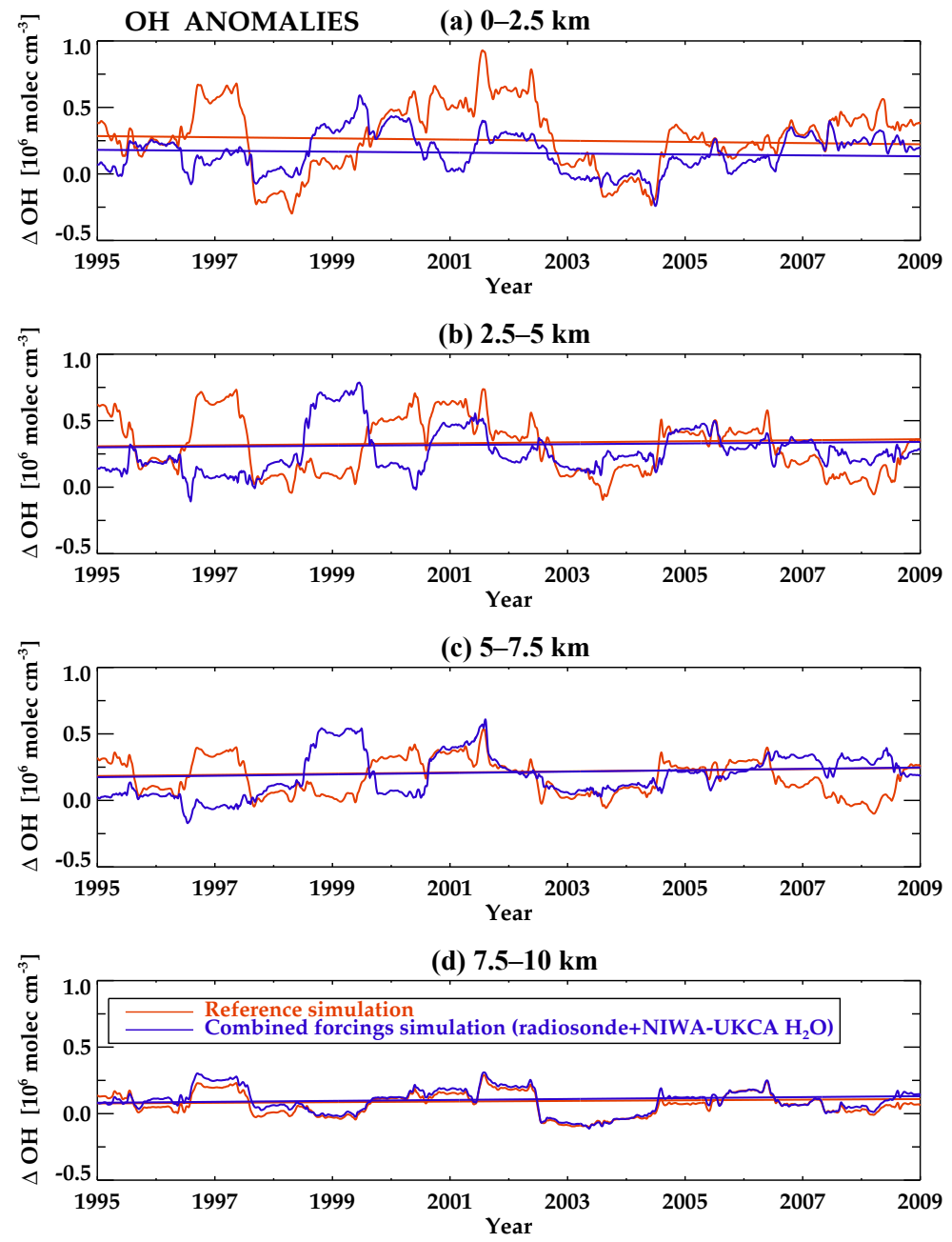

Figure 10. Variability and trends of the $\mathrm{OH}$ anomalies at different altitudes: (a) $0-2.5$, (b) $2.5-5$, (c) $5-7.5$, and (d) $7.5-10 \mathrm{~km}$. The red solid line is the time series of the reference simulation and the blue solid line is the combined forcings simulation considering radiosonde NIWA-UKCA $\mathrm{H}_{2} \mathrm{O}$.

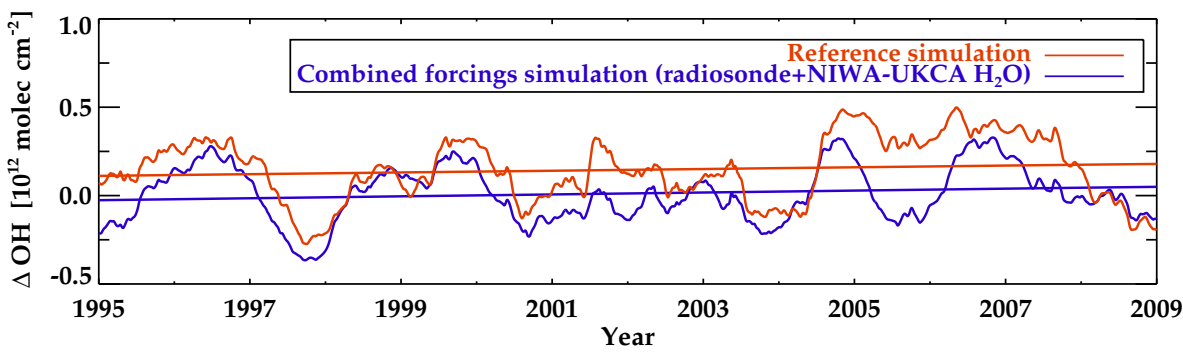

Figure 11. Variability and trend of the $\mathrm{OH}$ column anomaly. The red solid line is the time series of the reference simulation and the blue solid line is the combined forcings simulation considering radiosonde - NIWA-UKCA $\mathrm{H}_{2} \mathrm{O}$.

eraged enhancement and reduction in $j_{\mathrm{O}^{1} \mathrm{D}}$ are about 2 and $6 \%$ respectively for the LWCs, similar to the response for the ICs' condition; this suggests that the cloud vertical distribution has a bigger effect on photolysis than the change in cloud water content (Tie et al., 2003).

\section{Conclusions}

The sensitivity of the $\mathrm{OH}$ abundance at Lauder to NIWAUKCA model biases in key forcing variables $\left(\mathrm{O}_{3}, \mathrm{H}_{2} \mathrm{O}\right.$, $\mathrm{CH}_{4}, \mathrm{CO}$, and temperature) have been quantified for clear- 
(a) Mean ice MMR

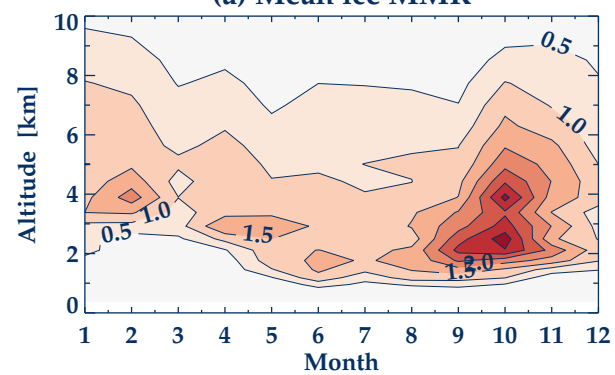

(c) Impact of ice on $\mathrm{j}\left(\mathrm{O}^{1} \mathrm{D}\right)$

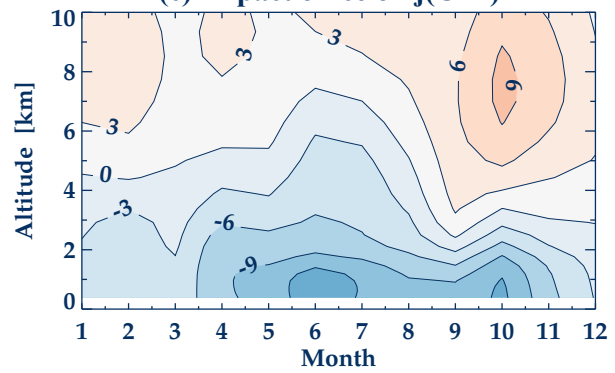

(e) $\mathrm{OH}$ change due to ice

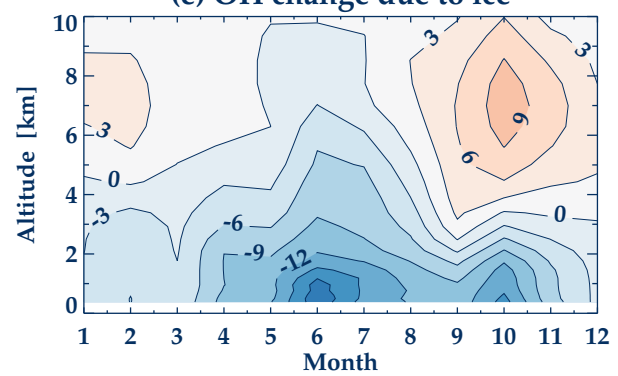

(g) $\mathrm{OH}$ change due to ice and LWC

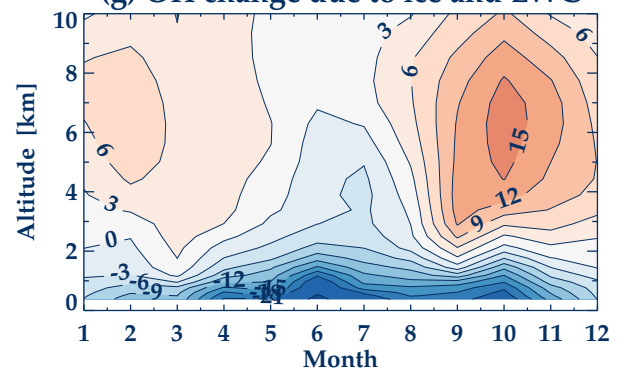

(b) Mean liquid water MMR

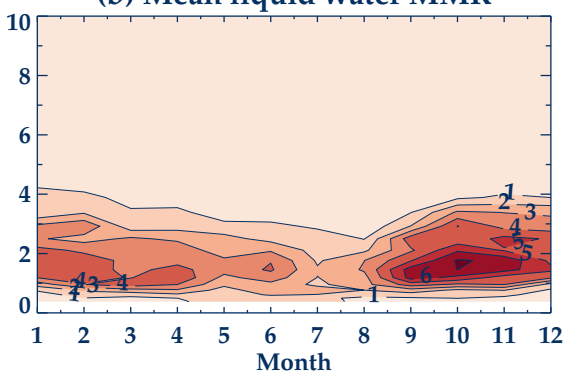

(d) Impact of LWC on j(O' D)

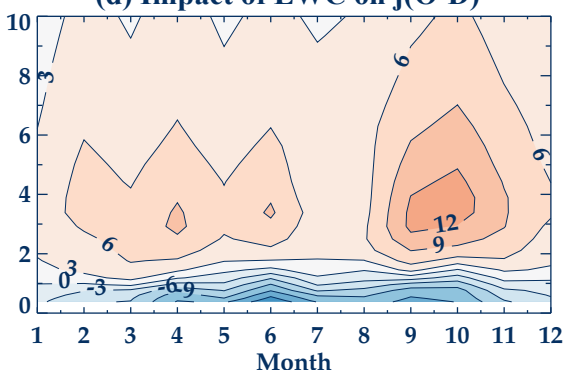

(f) $\mathrm{OH}$ change to to LWC

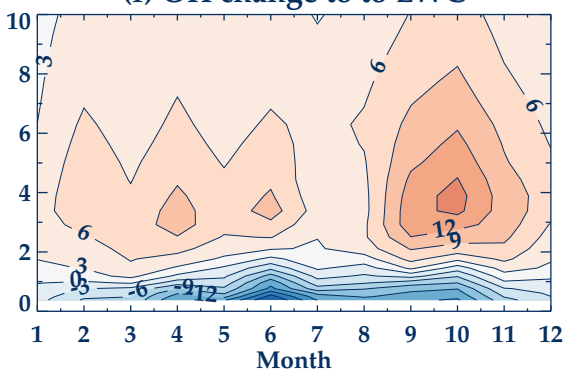

(h) Sum of (e) and (f)

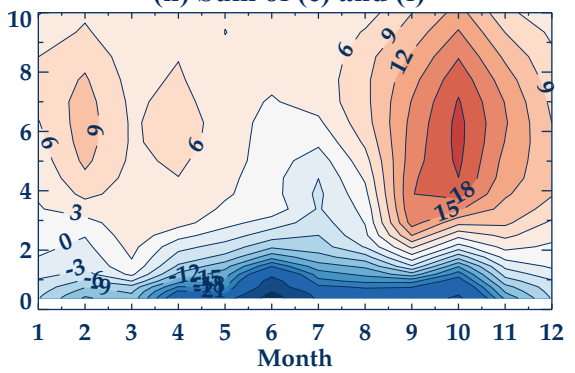

Figure 12. Multi-annual and monthly-mean $\mathrm{OH}$ responses to the presence of clouds. Multi-annual and monthly mean (a) ice content $\left(10^{-5} \mathrm{~kg} \mathrm{~kg}^{-1}\right)$. (b) liquid water content $\left(10^{-5} \mathrm{~kg} \mathrm{~kg}^{-1}\right)$. (c) Response of $j_{\mathrm{O}^{1} \mathrm{D}}(\%)$ to the presence of ICs relative to the cloud-free reference simulation. (d) response of $j_{\mathrm{O}^{1} \mathrm{D}}(\%)$ to the presence of LWCs relative to the cloud-free reference simulation. (e) response of $\mathrm{OH}$ (\%) to the presence of ICs relative to the cloud-free reference simulation. (f) Response of OH (\%) to the presence of LWCs relative to the cloud-free reference simulation. (g) response of $\mathrm{OH}(\%)$ to the presence of both LWCs and ICs relative to the cloud-free reference simulation. (h) Sum of (e) and (f).

sky conditions, using a single-column model. Only fast photochemistry is represented in the SCM; slow chemistry (i.e. timescales similar to or longer than the $1 \mathrm{~h}$ chemical timestep), transport, and other physical processes are thus not considered. The bias-corrected profiles of the key forcing variables have been constructed largely using long-term Lauder measurements, combined with NIWA-UKCA out- put. A few other sources of data (Cape Grim methane measurements, ERA-Interim water vapour) have also been used.

The results show that $\mathrm{OH}$ responds approximately linearly to correcting biases in $\mathrm{O}_{3}, \mathrm{H}_{2} \mathrm{O}, \mathrm{CH}_{4}, \mathrm{CO}$, and temperature. We have decomposed the $\mathrm{OH}$ response to $\mathrm{O}_{3}$ changes into the kinetic effect (i.e. local impacts on the chemical steady state of changing $\left[\mathrm{O}_{3}\right]$ ) and the photolysis effect (as mediated 
by changes in the overhead $\mathrm{O}_{3}$ column affecting photolysis rates). We find that the kinetic effect of correcting positive biases in modelled $\mathrm{O}_{3}$ causes a reduction in $\mathrm{OH}$ during austral summer and autumn (by up to $20 \%$ at $7 \mathrm{~km}$ ), and an increase in the free troposphere in austral spring (of $>5 \%$ in October at $3 \mathrm{~km}$ ); such changes in $\mathrm{OH}$ are nearly linearly related to the corresponding ozone biases. NIWA-UKCA generally overestimates the ozone column. Correcting this bias causes $j_{\mathrm{O}^{1} \mathrm{D}}$ to increase by $15-30 \%$ below $10 \mathrm{~km}$, causing general $\mathrm{OH}$ increases which maximize at around $16 \%$ between 2 and $6 \mathrm{~km}$ in summer. The model responds approximately linearly to the combined effects of photolysis and kinetics.

NIWA-UKCA considerably overestimates the $\mathrm{H}_{2} \mathrm{O}$ vapour concentration by up to $\sim 50 \%$ compared to radiosonde measurements. Correcting this moist bias leads to $>34 \%$ reductions in $\mathrm{OH}$ in the free troposphere during the austral summer. The sensitivity coefficient of $\mathrm{OH}$ to biases in $\mathrm{H}_{2} \mathrm{O}$ vapour is relatively large in the lower troposphere but decreases with altitude. Assuming this moist bias is not restricted to Lauder (which we do not assess here), this is thus a leading explanation for NIWA-UKCA to produce an underestimated $\mathrm{CH}_{4}$ lifetime (Morgenstern et al., 2013; Telford et al., 2013), relative to literature estimates (Naik et al., 2013; Voulgarakis et al., 2013; SPARC, 2013).

The bias in modelled $\mathrm{CH}_{4}$ is small since surface $\mathrm{CH}_{4}$ in the SCM reference simulation is constrained to follow globally averaged surface observations. The Southern Hemisphere generally has a slightly smaller $\mathrm{CH}_{4}$ burden than the Northern Hemisphere. Correcting the resulting positive bias at Lauder causes increases in $\mathrm{OH}$ throughout the troposphere, with a seasonal peak in March/April. OH is most sensitive to $\mathrm{CH}_{4}$ changes in winter, though. In the analysis of the $\mathrm{OH}$ sensitivity to $\mathrm{CH}_{4}$, the impact of subsequent changes in $\mathrm{CH}_{4}$ oxidation products which also affect $\mathrm{OH}$ could not be addressed within the constraints of an SCM. Inclusion of this effect could change the sensitivity coefficient for $\mathrm{CH}_{4}$ (Spivakovsky et al., 2000).

Except for October-December, NIWA-UKCA has a tendency to underestimate $\mathrm{CO}$. As with $\mathrm{CH}_{4}$, the sensitivity of $\mathrm{OH}$ to changes in $\mathrm{CO}$ is negative throughout the troposphere, reflecting that $\mathrm{CO}+\mathrm{OH}$ is an important sink for $\mathrm{OH}$.

We show that $\mathrm{OH}$ responds linearly to temperature biases. These effects cause a reduction in $\mathrm{OH}$ due to the strong dependence of $\mathrm{OH}+\mathrm{CH}_{4}$ on temperature (Eq. 1). However, the impact of this reaction on $\mathrm{OH}$ is buffered by other less temperature-dependent reactions, causing only a small sensitivity of $\mathrm{OH}$ to temperature. This is in agreement with O'Connor et al. (2009).

The results of the simulation considering simultaneous changes in all the key forcings indicate that $\mathrm{OH}$ responds approximately linearly to all the major forcings that contribute to the oxidizing capacity of the atmosphere. We find that biases in $\mathrm{O}_{3}, \mathrm{H}_{2} \mathrm{O}, \mathrm{CH}_{4}, \mathrm{CO}$, and temperature all affect the oxidizing capacity of the atmosphere at Lauder, with $\mathrm{H}_{2} \mathrm{O}$ and $\mathrm{O}_{3}$ biases dominating. We find no significant trend in OH over Lauder over the period 1994-2010.

The SCM approach can be applied to other parts of the globe where reliable long-term observations of $\mathrm{O}_{3}$ and $\mathrm{H}_{2} \mathrm{O}$ exist. In situ observations of $\mathrm{CH}_{4}$ and $\mathrm{CO}$ are not that critical; $\mathrm{CH}_{4}$ can be estimated from non-local measurements, and relatively reliable satellite measurements of total-column $\mathrm{CO}$ exist (e.g. Pan et al., 1995; Morgenstern et al., 2012). However, in polluted regions, such as in much of the Northern Hemisphere, $\mathrm{NO}_{x}$ and NMVOC levels are elevated relative to Lauder and affect in situ ozone production. This means that these constituents might need to be bias-corrected if the SCM is applied in such regions. This might affect the suitability of our approach under these conditions.

Having determined the contributions of the major forcings to the chemistry of $\mathrm{OH}$ at Lauder under clear-sky conditions, a step forward would be to assess the impact of clouds on photolysis and thus $\mathrm{OH}$, which could be substantial. Due to a lack of suitable observations to constrain the SCM model with cloud profiles at Lauder, we only assessed how the presence of modelled cloud affects $\mathrm{OH}$, relative to the clearsky situation. The results show that $\mathrm{OH}$ response to cloud strongly depends on the vertical distribution of the clouds, not just the total amount. Both liquid and ice clouds lead to increases in $\mathrm{OH}$ above and to some extent inside the cloud, particularly in the spring season when this effect maximizes. Considering that clouds are amongst the most difficult aspects of the climate system to model adequately, we stipulate that observational profiles of cloud properties would be highly desirable to use for a future continuation of this line of research.

In summary, we conclude that at Lauder, $\mathrm{OH}$ modelled in NIWA-UKCA is most sensitive to issues with representing water vapour and ozone. This points to the need to improve representations of the hydrological cycle and of tropospheric and stratospheric ozone chemistry in NIWA-UKCA and possibly other, similar chemistry-climate models. Water vapour is coupled to clouds in NIWA-UKCA; it is well known that clouds are difficult to represent adequately in global lowresolution climate models. The biases in ozone may well be partly caused by the moist bias in NIWA-UKCA; this is a subject of ongoing research.

Progress with the simulation of the hydrological cycle in present-generation Earth system models should improve the simulated water vapour product. Simulating an accurate hydrological cycle has been a long-standing issue in climate models, and progress has been slow. If errors in the simulation of moisture cannot be avoided, perhaps their impact on $\mathrm{OH}$ can be corrected for using an approach similar to that which we have presented but using global water vapour measurements. Such a "correction" of modelled OH might result in a reduction in the inter-model spread of the $\mathrm{OH}$ abundance and consequently a more accurate quantification of the methane lifetime. For this, tropical radiosonde data would be particularly valuable - most $\mathrm{OH}$ is located in the tropics 
(SPARC, 2013). A similar approach could be used to account for the influence of errors in ozone, although tropospheric in situ ozone measurements may be too sparse to allow for a sufficient characterization of the error in models.

\section{Data availability}

All data used in this work (both model forcing data and model output), as well as the single-column model itself, can be obtained from the contact author upon request. Forcing data have been obtained from NDACC and other public archives (see main text for details). The NIWA-UKCA simulation data have been submitted to the Centre for Environmental Data Analysis (CEDA) for public access. Instructions for downloading this data are at http://blogs.reading.ac.uk/ ccmi/badc-data-access/.

Author contributions. Olaf Morgenstern devised the original idea. Laura López-Comí wrote the model, conducted the simulations, performed the data analysis, and led the writing of the paper, with support from Sarah Masters, Olaf Morgenstern, and Guang Zeng. Gerald Nedoluha contributed the microwave ozone data to the research; Richard Querel contributed the ozone sonde data. All authors contributed to the writing of the manuscript.

Acknowledgements. This work has been supported by NIWA as part of its Government-funded, core research. We would like to thank the Lauder team for providing most of the measurements used here. We particularly thank Dan Smale for his help with various aspects of this work. We acknowledge NOAA for the FPH data. We acknowledge ECMWF for provision of the ERA-Interim data and NOAA/OAR/ESRL PSD, Boulder, Colorado, USA, for provision of the NCEP/NCAR reanalyses. We acknowledge CSIRO Marine and Atmospheric Research and the Australian Bureau of Meteorology for the Cape Grim methane measurements. CSIRO and the Australian Bureau of Meteorology give no warranty regarding the accuracy, completeness, currency or suitability for any particular purpose, and accept no liability, in respect of data. We acknowledge the U.K. Met Office for use of the MetUM. Furthermore, we acknowledge the contribution of NeSI high-performance computing facilities to the results of this research. NZ's national facilities are provided by the NZ eScience Infrastructure and funded jointly by NeSI's collaborator institutions and through MBIE's Infrastructure programme (https://www.nesi.org.nz).

Edited by: W. Bloss

Reviewed by: two anonymous referees

\section{References}

Badosa, J., McKenzie, R. L., Kotkamp, M., Calbó, J., González, J. A., Johnston, P. V., O'Neill, M., and Anderson, D. J.: Towards closure between measured and modelled UV under clear skies at four diverse sites, Atmos. Chem. Phys., 7, 2817-2837, doi:10.5194/acp-7-2817-2007, 2007.

Bergman, J. and Sardeshmukh, P.: Dynamic stabilization of atmospheric single column models, J. Clim., 17, 1004-1021, 2004.

Bloss, W. J., Lee, J. D., Heard, D. E., Salmon, R. A., Bauguitte, S. J. B., Roscoe, H. K., and Jones, A. E.: Observations of $\mathrm{OH}$ and $\mathrm{HO}_{2}$ radicals in coastal Antarctica, Atmos. Chem. Phys., 7, 4171-4185, doi:10.5194/acp-7-4171-2007, 2007.

Bodeker, G. E., Boyd, I. S., and Matthews, W. A.: Trends and variability in vertical ozone and temperature profiles measured by ozonesondes at Lauder, New Zealand: 1986-1996, J. Geophys. Res., 103, 28661-28681, 1998.

Bousquet, P., Hauglustaine, D. A., Peylin, P., Carouge, C., and Ciais, P.: Two decades of $\mathrm{OH}$ variability as inferred by an inversion of atmospheric transport and chemistry of methyl chloroform, Atmos. Chem. Phys., 5, 2635-2656, doi:10.5194/acp-52635-2005, 2005.

Boyd, I. S., Parrish, A. D., Froidevaux, L., von Clarmann. T., Kyrölä, E., Russell III, J. M., and Zawodny, J. M.: Groundbased microwave ozone radiometer measurements compared with Aura-MLS v2.2 and other instruments at two Network for Detection of Atmospheric Composition Change sites, J. Geophys. Res. Atmos., 112, D24S33, doi:10.1029/2007JD008720, 2007.

Carver, G., Brown, P., and Wild, O.: The ASAD atmospheric chemistry integration package and chemical reaction database, Comp. Phys. Comm., 105, 197-215, doi:10.1016/S00104655(97)00056-8, 1997.

Creasey, D., Evans, G., Heard, D., and Lee, J.: Measurements of $\mathrm{OH}$ and $\mathrm{HO}_{2}$ concentrations in the Southern Ocean marine boundary layer, , J. Geophys. Res. Atmos., 108, 4475, doi:10.1029/2002JD003206, 2003.

Cunnold, D. M., Steele, L. P., Fraser, P. J., Simmonds, P. G., Prinn, R. G., Weiss, R. F., Porter, L. W., O’Doherty, S., Langenfelds, R. L., Krummel, P. B., Wang, H. J., Emmons, L., Tie, X. X., and Dlugokencky, E. J.: In situ measurements of atmospheric methane at GAGE/AGAGE sites during 1985-2000 and resulting source inferences, J. Geophys. Res. Atmos., 107, 1-18, doi:10.1029/2001JD001226, 2002.

Cuxart, J., Holtslag, A., Beare, R., Bazile, E., Beljaars, A., Cheng, A., Conangla, L., Ek, M., Freedman, F., Hamdi, R., Kerstein, A., Kitagawa, H., Lenderink, G., Lewellen, D., Mailhot, J., Mauritsen, T., Perov, V., Schayes, G., Steeneveld, G., Svensson, G., Taylor, P., Weng, W., Wunsch, S., and Xu, K.: Single-column model intercomparison for a stably stratified atmospheric boundary layer, Bound.-Layer Meteor., 118, 273-303, 2006.

Dal Gesso, S., van der Dussen, J. J., Siebesma, A. P., de Roode, S. R., Boutle, I. A., Kamae, Y., Roehrig, R., and Vial, J.: A singlecolumn model intercomparison on the stratocumulus representation in present-day and future climate, J. Adv. Mod. Earth Systems, 7, 617-647, doi:10.1002/2014MS000377, 2015.

Dee, D., Uppala, S., Simmons, A., Berrisford, P., Poli, P., Kobayashi, S., Andrae, U., Balmaseda, M., Balsamo, G., Bauer, P., Bechtold, P., Beljaars, A., van de Berg, L., Bidlot, J., Bormann, N., Delsol, C., Dragani, R., Fuentes, M., Geer, A., Haimberger, L., Healy, S., Hersbach, H., Hólm, E., Isaksen, L., Kållberg, P., Köhler, M., Matricardi, M., McNally, A., MongeSanz, B., Morcrette, J.-J., Park, B.-K., Peubey, C., de Rosnay, P., Tavolato, C., Thepaut, J.-N., and Vitart, F.: The ERA- 
Interim reanalysis: configuration and performance of the data assimilation system, Q. J. Roy. Meteorol. Soc., 137, 553-597, doi:10.1002/qj.828, 2011.

DeMore, W. B.: Experimental and estimated rate constants for the reactions of hydroxyl radicals with several halocarbons, J. Phys. Chem., 100, 5813-5820, doi:10.1021/jp953216, 1996.

Dentener, F., Peters, W., Krol, M., van Weele, M., Bergamaschi, P., and Lelieveld, J.: Interannual variability and trend of $\mathrm{CH}_{4}$ lifetime as a measure for $\mathrm{OH}$ changes in the 19791993 time period, J. Geophys. Res. Atmos., 108, 4442, doi:10.1029/2002JD002916, 2003.

Dusanter, S., Vimal, D., Stevens, P. S., Volkamer, R., and Molina, L. T.: Measurements of $\mathrm{OH}$ and $\mathrm{HO}_{2}$ concentrations during the MCMA-2006 field campaign - Part 1: Deployment of the Indiana University laser-induced fluorescence instrument, Atmos. Chem. Phys., 9, 1665-1685, 2009.

Elshorbany, Y. F., Kleffmann, J., Hofzumahaus, A., Kurtenbach, R., Wiesen, P., Brauers, T., Bohn, B., Dorn, H.-P., Fuchs, H., Holland, F., Rohrer, F., Tillmann, R., Wegener, R., Wahner, A., Kanaya, Y., Yoshino, A., Nishida, S., Kajii, Y., Martinez, M., Kubistin, D., Harder, H., Lelieveld, J., Elste, T., Plass-Dülmer, C., Stange, G., Berresheim, H., and Schurath, U.: $\mathrm{HO}_{x}$ budgets during $\mathrm{HO}_{x}$ Comp: A case study of $\mathrm{HO}_{x}$ chemistry under $\mathrm{NO}_{x}$-limited conditions, J. Geophys. Res. Atmos., 117, D03307, doi:10.1029/2011JD017008, 2012.

Emmerson, K., Carslaw, N., Carpenter, L., Heard, D., Lee, J., and Pilling, M.: Urban atmospheric chemistry during the PUMA campaign 1: Comparison of modelled $\mathrm{OH}$ and $\mathrm{HO}_{2}$ concentrations with measurements, J. Atmos. Chem., 52, 143-164, 2005.

Emmerson, K. M., Carslaw, N., Carslaw, D. C., Lee, J. D., McFiggans, G., Bloss, W. J., Gravestock, T., Heard, D. E., Hopkins, J., Ingham, T., Pilling, M. J., Smith, S. C., Jacob, M., and Monks, P. S.: Free radical modelling studies during the UK TORCH campaign in summer 2003, Atmos. Chem. Phys., 7, 167-181, doi:10.5194/acp-7-167-2007, 2007.

Eyring, V., Lamarque, J.-F., Hess, P., Arfeuille, F., Bowman, K., Chipperfield, M. P., Duncan, B., Fiore, A., Gettelman, A., Giorgetta, M. A., Granier, C., Hegglin, M. I., Kinnison, D., Kunze, M., Langematz, U., Luo, B. P., Martin, R., Matthes, K., Newman, P. A., Peter, T., Robock, A., Ryerson, T., Saiz-Lopez, A., Salawitch, R., Schultz, M., Shepherd, T. G., Shindell, D., Staehelin, J., Tegtmeier, S., Thomason, L., Tilmes, S., Vernier, J.P., Waugh, D. W., and Young, P. J.: Overview of IGAC/SPARC Chemistry-Climate Model Initiative (CCMI) community simulations in support of upcoming ozone and climate assessments, SPARC Newsletter, 40, 48-66, 2013.

Fuglestvedt, J., Jonson, J., and Isaksen, I.: Effects of reductions in stratospheric ozone on tropospheric chemistry through changes in photolysis rates, Tellus B, 46, 172-192, 1994.

Hall, E. G., Jordan, A. F., Hurst, D. F., Oltmans, S. J., Vömel, H., Kühnreich, B., and Ebert, V.: Advancements, measurement uncertainties, and recent comparisons of the NOAA frost point hygrometer, Atmos. Meas. Tech., 9, 4295-4310, doi:10.5194/amt9-4295-2016, 2016.

Heard, D. E. and Pilling, M. J.: Measurement of $\mathrm{OH}$ and $\mathrm{HO}_{2}$ in the troposphere, Chem. Rev., 103, 5163-5198, 2003.

Hess, P. and Mahowald, N.: Interannual variability in hindcasts of atmospheric chemistry: the role of meteorology, Atmos. Chem. Phys., 9, 5261-5280, doi:10.5194/acp-9-5261-2009, 2009.
Holmes, C. D., Prather, M. J., Søvde, O. A., and Myhre, G.: Future methane, hydroxyl, and their uncertainties: key climate and emission parameters for future predictions, Atmos. Chem. Phys., 13, 285-302, doi:10.5194/acp-13-285-2013, 2013.

John, J. G., Fiore, A. M., Naik, V., Horowitz, L. W., and Dunne, J. P.: Climate versus emission drivers of methane lifetime against loss by tropospheric OH from 1860-2100, Atmos. Chem. Phys., 12, 12021-12036, doi:10.5194/acp-12-12021-2012, 2012.

Johnson, C. E., Stevenson, D. S., Collins, W. J., and Derwent, R. G.: Role of climate feedback on methane and ozone studied with a Coupled Ocean-Atmosphere-Chemistry Model, Geophys. Res. Lett., 28, 1723-1726, doi:10.1029/2000GL011996, 2001.

Joyce, P. L., von Glasow, R., and Simpson, W. R.: The fate of $\mathrm{NO}_{\mathrm{x}}$ emissions due to nocturnal oxidation at high latitudes: 1-D simulations and sensitivity experiments, Atmos. Chem. Phys., 14, 7601-7616, doi:10.5194/acp-14-7601-2014, 2014.

Kalnay, E., Kanamitsu, M., Kistler, R., Collins, W., Deaven, D., Gandin, L., Iredell, M., Saha, S., White, G., Woollen, J., Zhu, Y., Chelliah, M., Ebisuzaki, W., Higgins, W., Janowiak, J., Mo, K., Ropelewski, C., Wang, J., Leetmaa, A., Reynolds, R., Jenne, R., and Joseph, D.: The NCEP/NCAR 40-year reanalysis project, Bull. Amer. Meteorol. Soc., 77, 437-470, 1996.

Krol, M. C., Meirink, J. F., Bergamaschi, P., Mak, J. E., Lowe, D., Jöckel, P., Houweling, S., and Röckmann, T.: What can ${ }^{14} \mathrm{CO}$ measurements tell us about $\mathrm{OH}$ ?, Atmos. Chem. Phys., 8, 50335044, doi:10.5194/acp-8-5033-2008, 2008.

Kylling, A., Webb, A., Kift, R., Gobbi, G., Ammannato, L., Barnaba, F., Bais, A., Kazadzis, S., Wendisch, M., Jakel, E., Schmidt, S., Kniffka, A., Thiel, S., Junkermann, W., Blumthaler, M., Silbernagl, R., Schallhart, B., Schmitt, R., Kjeldstad, B., Thorseth, T., Scheirer, R., and Mayer, B.: Spectral actinic flux in the lower troposphere: measurement and 1-D simulations for cloudless, broken cloud and overcast situations, Atmos. Chem. Phys., 5, 1975-1997, 2005.

Lebassi-Habtezion, B. and Caldwell, P. M.: Aerosol specification in single-column Community Atmosphere Model version 5, Geosci. Model Dev., 8, 817-828, doi:10.5194/gmd-8-817-2015, 2015.

Lelieveld, J. and Dentener, F. J.: What controls tropospheric ozone?, J. Geophys. Res. Atmos., 105, 3531-3551, doi:10.1029/1999jd901011, 2000.

Lelieveld, J., Crutzen, P. J., and Dentener, F. J.: Changing concentration, lifetime and climate forcing of atmospheric methane, Tellus B, 50, 128-150, doi:10.1034/j.1600-0889.1998.t01-1-00002.x, 1998.

Lelieveld, J., Dentener, F. J., Peters, W., and Krol, M. C.: On the role of hydroxyl radicals in the self-cleansing capacity of the troposphere, Atmos. Chem. Phys., 4, 2337-2344, doi:10.5194/acp4-2337-2004, 2004.

Levy, H.: Normal atmosphere: Large radical and formaldehyde concentrations predicted, Science, 173, 141-143, 1971.

Liu, H., Crawford, J. H., Considine, D. B., Platnick, S., Norris, P. M., Duncan, B. N., Pierce, R. B., Chen, G., and Yantosca, R. M.: Sensitivity of photolysis frequencies and key tropospheric oxidants in a global model to cloud vertical distributions and optical properties, , J. Geophys. Res. Atmos., 114, D10305, doi:10.1029/2008JD011503, 2009. 
Liu, S. C. and Trainer, M.: Response of the tropospheric ozone and odd hydrogen radicals to column ozone change, J. Atmos. Chem., 6, 221-233, 1988.

Logan, J. A., Prather, M. J., Wofsy, S. C., and McElroy, M. B.: Tropospheric chemistry: A global perspective, J. Atmos. Chem., 86, 7210-7254, doi:10.1029/jc086ic08p07210, 1981.

López Comí, L.: Single-column model analysis of available NIWA observations to determine the self-cleaning capacity of the atmosphere, PhD thesis, U. Canterbury, Christchurch, 2016.

Madronich, S. and Granier, C.: Impact of recent total changes on tropospheric ozone photodissociation, hydroxyl radicals, and methane trends, Geophys. Res. Lett., 19, 465-467, 1992.

Manning, M., Lowe, D., Moss, R., Bodeker, G., and Allan, W.: Short-term variations in the oxidizing power of the atmosphere, Nature, 436, 1001-1004, 2005.

McKenzie, R. L., Weinreis, C., Johnston, P. V., Liley, B., Shiona, H., Kotkamp, M., Smale, D., Takegawa, N., and Kondo, Y.: Effects of urban pollution on UV spectral irradiances, Atmos. Chem. Phys., 8, 5683-5697, doi:10.5194/acp-8-5683-2008, 2008.

Meinshausen, M., Smith, S. J., Calvin, K. V., Daniel, J. S., Kainuma, M. L. T., Lamarque, J.-F., Matsumoto, K., Montzka, S., Raper, S., Riahi, K., Thomson, A. M., Velders, G. J. M., and van Vuuren, D. P.: The RCP greenhouse gas concentrations and their extensions from 1765 to 2300, Climatic Change, 109, 213-241, doi:10.1007/s10584-011-0156-z, 2011.

Mihailovic, D., Rao, S., Alapaty, K., Ku, J., Arsenic, I., and Lalic, B.: A study on the effects of subgrid-scale representation of land use on the boundary layer evolution using a 1-D model, Environ. Mod. Soft., 20, 705-714, doi:10.1016/j.envsoft.2004.04.004, 2005.

Miloshevich, L., Vömel, H., Paukkunen, A., Heymsfield, A., and Oltmans, S.: Characterization and correction of relative humidity measurements from vaisala RS80-A radiosondes at cold temperatures, J. Atmos. Ocean. Technol., 18, 135-156, 2001.

Montzka, S. A., Krol, M., Dlugokencky, E., Hall, B., Jöckel, P., and Lelieveld, J.: Small interannual variability of global atmospheric hydroxyl, Science, 331, 67-69, 2011.

Morgenstern, O., Braesicke, P., O’Connor, F. M., Bushell, A. C., Johnson, C. E., Osprey, S. M., and Pyle, J. A.: Evaluation of the new UKCA climate-composition model - Part 1: The stratosphere, Geosci. Model Dev., 2, 43-57, doi:10.5194/gmd-2-432009, 2009.

Morgenstern, O., Zeng, G., Wood, S. W., Robinson, J., Smale, D., Paton-Walsh, C., Jones, N. B., and Griffith, D. W. T.: Long-range correlations in Fourier transform infrared, satellite, and modeled CO in the Southern Hemisphere, J. Geophys. Res., 117, D11301, doi:10.1029/2012JD017639, 2012.

Morgenstern, O., Zeng, G., Abraham, N. L., Telford, P. J., Braesicke, P., Pyle, J. A., Hardiman, S. C., O'Connor, F. M., and Johnson, C. E.: Impacts of climate change, ozone recovery, and increasing methane on surface ozone and the tropospheric oxidizing capacity, J. Geophys. Res. Atmos., 118, 1028-1041, doi:10.1029/2012JD018382, 2013.

Morgenstern, O., Hegglin, M. I., Rozanov, E., O’Connor, F. M., Abraham, N. L., Akiyoshi, H., Archibald, A. T., Bekki, S., Butchart, N., Chipperfield, M. P., Deushi, M., Dhomse, S. S., Garcia, R. R., Hardiman, S. C., Horowitz, L. W., Jöckel, P., Josse, B., Kinnison, D., Lin, M. Y., Mancini, E., Manyin, M. E., Marchand, M., Marécal, V., Michou, M., Oman, L. D., Pitari, G.,
Plummer, D. A., Revell, L. E., Saint-Martin, D., Schofield, R., Stenke, A., Stone, K., Sudo, K., Tanaka, T. Y., Tilmes, S., Yamashita, S., Yoshida, Y., and Zeng, G.: Review of the global models used within the Chemistry-Climate Model Initiative (CCMI), Geosci. Model Dev. Discuss, doi:10.5194/gmd-2016-199, 2016.

Naik, V., Voulgarakis, A., Fiore, A. M., Horowitz, L. W., Lamarque, J.-F., Lin, M., Prather, M. J., Young, P. J., Bergmann, D., Cameron-Smith, P. J., Cionni, I., Collins, W. J., Dalsøren, S. B., Doherty, R., Eyring, V., Faluvegi, G., Folberth, G. A., Josse, B., Lee, Y. H., MacKenzie, I. A., Nagashima, T., van Noije, T. P. C., Plummer, D. A., Righi, M., Rumbold, S. T., Skeie, R., Shindell, D. T., Stevenson, D. S., Strode, S., Sudo, K., Szopa, S., and Zeng, G.: Preindustrial to present-day changes in tropospheric hydroxyl radical and methane lifetime from the Atmospheric Chemistry and Climate Model Intercomparison Project (ACCMIP), Atmos. Chem. Phys., 13, 5277-5298, doi:10.5194/acp13-5277-2013, 2013.

Nedoluha, G. E., Boyd, I. S., Parrish, A., Gomez, R. M., Allen, D. R., Froidevaux, L., Connor, B. J., and Querel, R. R.: Unusual stratospheric ozone anomalies observed in 22 years of measurements from Lauder, New Zealand, Atmos. Chem. Phys., 15, 6817-6826, doi:10.5194/acp-15-6817-2015, 2015.

Neu, J. L., Prather, M. J., and Penner, J. E.: Global atmospheric chemistry: Integrating over fractional cloud cover, , J. Geophys. Res. Atmos., 112, D11306, doi:10.1029/2006JD008007, 2007.

O'Connor, F. M., Johnson, C. E., Morgenstern, O., Abraham, N. L., Braesicke, P., Dalvi, M., Folberth, G. A., Sanderson, M. G., Telford, P. J., Voulgarakis, A., Young, P. J., Zeng, G., Collins, W. J., and Pyle, J. A.: Evaluation of the new UKCA climatecomposition model - Part 2: The Troposphere, Geosci. Model Dev., 7, 41-91, doi:10.5194/gmd-7-41-2014, 2014.

O'Connor, F. M., Johnson, C. E., Morgenstern, O., and Collins, W. J.: Interactions between tropospheric chemistry and climate model temperature and humidity biases, Geophys. Res. Lett., 36, L16801, doi:10.1029/2009GL039152, 2009.

Pan, L., Edwards, D. P., Gille, J. C., Smith, M. W., and Drummond, J. R.: Satellite remote sensing of tropospheric $\mathrm{CO}$ and $\mathrm{CH}_{4}$ : forward model studies of the MOPITT instrument, Appl. Opt., 34, 6976-6988, doi:10.1364/AO.34.006976, 1995.

Piot, M. and von Glasow, R.: The potential importance of frost flowers, recycling on snow, and open leads for ozone depletion events, Atmos. Chem. Phys., 8, 2437-2467, 2008.

Pöschl, U., von Kuhlmann, R., Poisson, N., and Crutzen, P. J.: Development and Intercomparison of Condensed Isoprene Oxidation Mechanisms for Global Atmospheric Modeling, J. Atmos. Chem., 37, 29-52, 2000.

Prinn, R., Huang, J., Weiss, R., Cunnold, D., Fraser, P., Simmonds, P., McCulloch, A., Harth, C., Reimann, S., Salameh, P., O'Doherty, S., Wang, R., Porter, L., Miller, B., and Krummel, P.: Evidence for variability of atmospheric hydroxyl radicals over the past quarter century, Geophys. Res. Lett., 32, L07809, doi:10.1029/2004GL022228, 2005.

Prinn, R. G.: Evidence for substantial variations of atmospheric hydroxyl radicals in the past two decades, Science, 293, 1048, doi:10.1126/science.1058673, 2001.

Randall, D., Krueger, S., Bretherton, C., Curry, J., Duynkerke, P., Moncrieff, M., Ryan, B., Starr, D., Miller, M., Rossow, W., Tselioudis, G., and Wielicki, B.: Confronting models with data - 
The GEWEX cloud systems study, Bull. Amer. Meteorol. Soc., 84, 455-469, 2003.

Rayner, N. A., Parker, D. E., Horton, E. B., Folland, C. K., Alexander, L. V., Rowell, D. P., Kent, E. C., and Kaplan, A.: Global analyses of sea surface temperature, sea ice, and night marine air temperature since the late nineteenth century, J. Geophys. Res., 108, 4407, doi:10.1029/2002JD002670, 2003.

Ren, X., Harder, H., Martinez, M., Lesher, R. L., Oliger, A., Simpas, J. B., Brune, W. H., Schwab, J. J., Demerjian, K. L., He, Y., Zhou, $\mathrm{X}$., and $\mathrm{Gao}, \mathrm{H} .: \mathrm{OH}$ and $\mathrm{HO}_{2}$ chemistry in the urban atmosphere of New York City, Atmos. Environ., 37, 3639-3651, 2003.

Rinsland, C., Jones, N., Connor, B., Logan, J., Pougatchev, N., Goldman, A., Murcray, F., Stephen, T., Pine, A., Zander, R., Mahieu, E., and Demoulin, P.: Northern and southern hemisphere ground-based infrared spectroscopic measurements of tropospheric carbon monoxide and ethane, J. Geophys. Res. Atmos., 103, 28197-28217, 1998.

Shindell, D. T., Faluvegi, G., Unger, N., Aguilar, E., Schmidt, G. A., Koch, D. M., Bauer, S. E., and Miller, R. L.: Simulations of preindustrial, present-day, and 2100 conditions in the NASA GISS composition and climate model G-PUCCINI, Atmos. Chem. Phys., 6, 4427-4459, doi:10.5194/acp-6-4427-2006, 2006.

SPARC: SPARC Report on the Lifetimes of Stratospheric OzoneDepleting Substances, Their Replacements, and Related Species, SPARC Report, 6, WCRP-15/2013, 2013.

Spivakovsky, C. M., Logan, J. A., Montzka, S. A., Balkanski, Y. J., Foreman-Fowler, M., Jones, D. B. A., Horowitz, L. W., Fusco, A. C., Brenninkmeijer, C. A. M., Prather, M. J., Wofsy, S. C., and McElroy, M. B.: Three-dimensional climatological distribution of tropospheric $\mathrm{OH}$ : Update and evaluation, J. Geophys. Res., 105, 8931-8980, 2000.

Stedman, D. H. and McEwan, M. J.: Oxides of nitrogen at two sites in New Zealand, Geophys. Res. Lett., 10, 168-171, doi:10.1029/GL010i002p00168, 1983.

Stevenson, D., Johnson, C., Collins, W., Derwent, R., and Edwards, J.: Future estimates of tropospheric ozone radiative forcing and methane turnover - the impact of climate change, Geophys. Res. Lett., 27, 2073-2076, 2000.

Stevenson, D., Dentener, F., Schultz, M., Ellingsen, K., van Noije, T., Wild, O., Zeng, G., Amann, M., Atherton, C., Bell, N., Bergmann, D., Bey, I., Butler, T., Cofala, J., Collins, W., Derwent, R., Doherty, R., Drevet, J., Eskes, H., Fiore, A., Gauss, M., Hauglustaine, D., Horowitz, L., Isaksen, I., Krol, M., Lamarque, J., Lawrence, M., Montanaro, V., Muller, J., Pitari, G., Prather, M., Pyle, J., Rast, S., Rodriguez, J., Sanderson, M., Savage, N., Shindell, D., Strahan, S., Sudo, K., and Szopa, S.: Multimodel ensemble simulations of present-day and near-future tropospheric ozone, J. Geophys. Res. Atmos., 111, D08301, doi:10.1029/2005JD006338, 2006.

Stone, K. A., Morgenstern, O., Karoly, D. J., Klekociuk, A. R., French, W. J., Abraham, N. L., and Schofield, R.: Evaluation of the ACCESS - chemistry-climate model for the Southern Hemisphere, Atmos. Chem. Phys., 16, 2401-2415, doi:10.5194/acp16-2401-2016, 2016.

Tang, Y., Carmichael, G. R., Uno, I., Woo, J.-H., Kurata, G., Lefer, B., Shetter, R. E., Huang, H., Anderson, B. E., Avery, M. A., Clarke, A. D., and Blake, D. R.: Impacts of aerosols and clouds on photolysis frequencies and photochemistry dur- ing TRACE-P: 2. Three-dimensional study using a regional chemical transport model, J. Geophys. Res. Atmos., 108, 8822, doi:10.1029/2002JD003100, 2003.

Telford, P. J., Abraham, N. L., Archibald, A. T., Braesicke, P., Dalvi, M., Morgenstern, O., O'Connor, F. M., Richards, N. A. D., and Pyle, J. A.: Implementation of the Fast-JX Photolysis scheme (v6.4) into the UKCA component of the MetUM chemistry-climate model (v7.3), Geosci. Model Dev., 6, 161177, doi:10.5194/gmd-6-161-2013, 2013.

Thompson, A. M.: The oxidizing capacity of the Earth's atmosphere: Probable past and future changes, Science, 256, 11571165, 1992.

Thompson, A. M., Stewart, R. W., Owens, M. A., and Herwehe, J. A.: Sensitivity of tropospheric oxidants to global chemical and climate change, Atmos. Environ., 23, 519-532, 1989.

Tie, X., Madronich, S., Walters, S., Zhang, R., Rasch, P., and Collins, W.: Effect of clouds on photolysis and oxidants in the troposphere, J. Geophys. Res. Atmos., 108, 4642, doi:10.1029/2003JD003659, 2003.

Vömel, H., David, D. E., and Smith, K.: Accuracy of tropospheric and stratospheric water vapor measurements by the cryogenic frost point hygrometer: Instrumental details and observations, J. Geophys. Res., 112, 8305, doi:10.1029/2006JD007224, 2007.

Voulgarakis, A., Naik, V., Lamarque, J.-F., Shindell, D. T., Young, P. J., Prather, M. J., Wild, O., Field, R. D., Bergmann, D., Cameron-Smith, P., Cionni, I., Collins, W. J., Dalsøren, S. B., Doherty, R. M., Eyring, V., Faluvegi, G., Folberth, G. A., Horowitz, L. W., Josse, B., MacKenzie, I. A., Nagashima, T., Plummer, D. A., Righi, M., Rumbold, S. T., Stevenson, D. S., Strode, S. A., Sudo, K., Szopa, S., and Zeng, G.: Analysis of present day and future $\mathrm{OH}$ and methane lifetime in the ACCMIP simulations, Atmos. Chem. Phys., 13, 2563-2587, doi:10.5194/acp-13-2563-2013, 2013.

Vupputuri, R., Higuchi, K., and Hengeveld, H.: A 1-D modelling of climatic and chemical effects of greenhouse gases, Theor. Appl. Climatol., 52, 151-167, doi:10.1007/BF00864039, 1995.

Wild, O.: Modelling the global tropospheric ozone budget: exploring the variability in current models, , Atmos. Chem. Phys., 7, 2643-2660, 2007.

Wild, O. and Palmer, P. I.: How sensitive is tropospheric oxidation to anthropogenic emissions?, Geophys. Res. Lett., 35, L22802, doi:10.1029/2008GL035718, 2008.

WMO: Scientific Assessment of Ozone Depletion: 2010, vol. 52 of Global Ozone Research and Monitoring Project, 516 pp., 2011.

Zeng, G., Pyle, J. A., and Young, P. J.: Impact of climate change on tropospheric ozone and its global budgets, Atmos. Chem. Phys., 8, 369-387, doi:10.5194/acp-8-369-2008, 2008.

Zeng, G., Morgenstern, O., Braesicke, P., and Pyle, J. A.: Impact of stratospheric ozone recovery on tropospheric ozone and its budget, Geophys. Res. Lett., 37, L09805, doi:10.1029/2010GL042812, 2010.

Zeng, G., Wood, S. W., Morgenstern, O., Jones, N. B., Robinson, J., and Smale, D.: Trends and variations in $\mathrm{CO}, \mathrm{C}_{2} \mathrm{H}_{6}$, and $\mathrm{HCN}$ in the Southern Hemisphere point to the declining anthropogenic emissions of $\mathrm{CO}$ and $\mathrm{C}_{2} \mathrm{H}_{6}$, Atmos. Chem. Phys., 12, 7543$7555,2012$. 